\title{
The Principle of Good Faith in the Palestinian Civil Code Draft and Its Role in Maintaining Economic Contractual Equilibrium at the Pre-Contracting Phase
}

\author{
Osama Ismail Mohammad Amayreh ${ }^{1}$, Izura Masdina Mohamed Zakri ${ }^{1}$, Pardis Moslemzadeh Tehrani ${ }^{1} \&$ Yousef \\ Mohammad Shandi ${ }^{2}$ \\ ${ }^{1}$ Faculty of Law, University of MALAYA, Kuala Lumpur, Malaysia \\ ${ }^{2}$ Faculty of Law, Arab American University, Palestine \\ Correspondence: Osama Ismail Mohammad Amayreh, Faculty of Law, University of MALAYA, 50603 Kuala \\ Lumpur, Malaysia. E-mail: advosama@outlook.com
}

Received: June 1, 2019

Accepted: July 25, 2019

Online Published: August 23, 2019

doi:10.5539/jpl.v12n3p113

URL: https://doi.org/10.5539/jpl.v12n3p113

\begin{abstract}
The jurisprudential and judicial legal trend tends to apply the principle of good faith at the pre-contracting phase as one of the most substantial principles governing this phase, since it is inconceivable that the parties are to negotiate in bad faith, and then must implement the contract in good faith, in accordance with the traditional legal rule that "fraud spoils everything it touches". However, the Palestinian legislature has ignored enacting legal provisions obliging the parties to abide by the principle of good faith in the pre-contracting phase causing a legislative deficiency in the legislative remedies of the subject of good faith in the pre-contracting phase. This paper seeks to prove that replacing a provision that requires good faith in negotiations with the provisions of tort liability causes many legal problems. To prove this, the legal provisions should be analysed which would also include determining the definition of the principle of good faith, and the function of that principle in achieving contractual equilibrium and the legal basis for this principle at the stage of negotiation which should also be analysed. Moreover, a comparative analytical approach with the French civil code is used to illustrate the Palestinian legislative deficiencies and the need to legislate a legal article which obligates the negotiating parties to behave in good faith, as this has become an unavoidable reality that should be dealt with to contribute to the stability of civil and commercial transactions. As such, the legal article should also specify the compensation to be claimed.
\end{abstract}

Keywords: principle of good faith, negotiations in pre-contracting phase, tort liability of pre-contracting phase, economic contractual equilibrium, Palestinian civil code draft

\section{Introduction}

The importance of negotiating the contract seems clear since it is in fact the period of preparation for the contract; the better the negotiations are, the better the contract will be without any deficiencies or ambiguities or arising future disputes. However, the negotiation process is a complicated process, with the bargaining, dialogue and insistence of the negotiating parties in order to achieve the desired interest of the contract which will be concluded, and with the least possible commitment both in the contract itself and during the negotiation phase. Each negotiating party wants to be in a position to resolve the obligations imposed by the legal principles that govern the phase of the negotiations. It also wants to divest the agreements that permeate the negotiations phase from any legal value and, not only that, but more importantly, to abandon and terminate the negotiations at a time when it wants to realize the principle of contractual freedom.

In order not to be a source of arbitrariness, this phase is governed by another principle: the principle of good faith, which is a mutual obligation of the parties to the negotiation and which arises once the parties enter into negotiations. However, in order to maintain the contractual economic balance between the parties to the negotiations, we are required us to study the concept of good faith and its function in maintaining the contractual balance between contractual parties and their legal nature. 


\section{Definition of the Principle of Good Faith}

The principle of good faith emerged with the rise of Roman law in what is known as the principle of (bonne foi), which was considered a source of legal rule in that period. ${ }^{1}$ Depending on it, the Roman judge was able to intervene to impose contractual obligations on the contracting parties in order to reach a state of contractual equilibrium whenever this equilibrium is disturbed. ${ }^{2}$ However, comparative legislations avoided providing a specific definition of the principle of good faith, given the existence of two contradictory trends: the first one recognized the importance of the principle of good faith in the regulation of contractual relations, but preferred to avoid providing a specific definition in order to give the judge wide authority to deal with it and with the presumption of its existence in the contractual relationship. ${ }^{3}$ While the second one denied the existence of this principle, so it was natural to avoid addressing its definition. ${ }^{4}$ In light of this reality, the US legislature has provided a definition of this principle as: "faithfulness to an agreed common purpose and consistency with the justified expectations of the other party". 5

Meanwhile, in reviewing the doctrinal definitions of the principle of good faith, it has two important dimensions: the subjective dimension and the objective dimension. ${ }^{6}$ It means, in the first dimension, a psychological or mental state based on ignorance of a particular occurrence, or in the mistaken and perverted belief or act, in the person's mind. ${ }^{7}$ The objective dimension (the second dimension), however, is about reliable external indicators in the search for the contractual economic equilibrium during the phases of the contract, ${ }^{8}$ which are ethical controls of conduct that are objectively assessed. ${ }^{9}$

Based on what has been stated above, comparative legal jurists developed the following definition of the principle of good faith: "the obligation of the contracting party to take into account the interests and expectations of the counterparty, ensuring the integrity of legal transactions and the balanced representation of the interests of the parties to the contractual relationship". ${ }^{10}$ Thus, the principle of good faith is a means by which the national judge can intervene to ensure the equilibrium of the contractual relations between the contracting parties. ${ }^{11}$

\section{Function of the Principle of Good Faith in Achieving Contractual Equilibrium at the Pre-Contracting Phase}

The contract theory is based on the principle of will autonomy, which includes the freedom of the contracting parties in determining the rights and obligations of their agreement. ${ }^{12}$ In other words, the principle of will autonomy means, inter alia, that human will is inherently free and can only be restricted by one's own will. ${ }^{13}$ However, in practice, reality proves beyond any doubt, that the ultimate application of the will autonomy principle may lead to disruption in the economic and legal positions of the parties to the contractual relationship,

\footnotetext{
${ }^{1}$ See Foldi, A. (2007). Remarks on the Notion of Bona Fides. Annales Universitatis Scientiarum Budapestinensis de Rolando Eotvos Nominatae: Sectio Iuridica 48, p 60-61. Sic, M. (2012). Fides and bona fides in the process of creating ius gentium. Zbornik Radova 46(2), p 176. Bonis, P. (2016). Bona fides exuberans: New Legal Concept of Twelfth Century Legal Scholarship. Journal on European History of Law 7(2), p 99.

${ }^{2}$ See Fayyad, M. (2014). Measures of the Principle of Good Faith in European Consumer Protection and Islamic Law, Comparative Analysis. Arab Law Quarterly 28(3), p 208-209.

${ }^{3}$ See the Official Explanatory of the Palestinian Civil Code Draft. Unpublished Manuscript. p 183.

${ }^{4}$ Juenger, F. K. (1994-1995). Listening to Law Professors Talk about Good Faith: Some Afterthoughts Tulane Law Review 69(5), $1253-1280$.

${ }^{5}$ See Feinman, J. M. (2014). Good Faith and Reasonable Expectations. Arkansas Law Review 67(3), p 527. Grossman, N. (2017). Jettisoning the Normative Value of the Implied Duty of Good Faith in Employment Law. Employee Rights and Employment Policy Journal $21(2), \mathrm{p} 382$.

${ }^{6}$ See Fayyad, M. (2014). Measures of the Principle of Good Faith in European Consumer Protection and Islamic Law, Comparative Analysis. Supra note, p 209.

${ }^{7}$ Nowicki, E. A. (2007). Director's Good Faith. Buffalo Law Review 55(2), p 525-526. Fayyad, M. (2014). Measures of the Principle of Good Faith in European Consumer Protection and Islamic Law, Comparative Analysis. Supra note, p 209.

${ }^{8}$ See Abdel Aal, H. M. (1998). The Conventional Organization of Contractual Negotiations. Cairo, Egypt: Dar Alnahdah Alearabiah. p 122. Spann, G. A. (2015). Good Faith Discrimination. William Mary Bill of Rights Journal 23(3), p 586-587. Luksic, B.; Jurilj, M. (2004). Principle of Good Faith in Contract Law. Zbornik Radova Pravnog Fakulteta Splitu 41(1-2), p 103.

${ }^{9}$ See Saleh, A. A. (2011). Negotiations in International Commercial Contracts. Algeria, Algeria: Dar Houma. p 393.

${ }^{10}$ See Nowicki, E. A. (2007). Director's Good Faith. Supra note, p 506-516. Fayyad, M. (2014). Measures of the Principle of Good Faith in European Consumer Protection and Islamic Law, Comparative Analysis. Supra note, p 210-211. Korde, R. (2000). Good Faith and Freedom of Contract. UCL Jurisprudence Review 2000, p 149.

${ }^{11}$ See Al Mulla, A. (2017). The Principle of Good Faith in Contracts: Qatari Law Perspective. Asian Business Lawyer 19, p 115-134.

${ }^{12}$ Fadily, I. (2009). Brief in the General Theory of Commitment. Algeria, Algeria: Diwan Almatbueat Aljamieiat. p 42-45.

${ }^{13}$ See Al Mulla, A. (2017). The Principle of Good Faith in Contracts: Qatari Law Perspective. Supra note, p 116.
} 
which creates a state of contractual economic imbalance between the contracting parties. ${ }^{14}$ Hence, the implementation of the principle of good faith in the area of contractual relations is indispensable, as a means through which the judge can intervene to impose certain obligations that restore the lost equilibrium to the contract. $^{15}$

Law jurists generally agreed that the principle of good faith has a significant role in enabling the judge to monitor and ensure contractual justice, ${ }^{16}$ by assuming the integrity in the contractual relationship and ensuring that each contracting party respects the interests and rights of the counterparty. Furthermore, this principle also helps to achieve a set of objectives, the most important of which are the following: firstly, limiting the legal intricacies in the literal application of some other legal principles, ${ }^{17}$ such as, the principle of will autonomy, contract binding force and inviolability of the contract, and filling the legislative deficiencies of the principle of contractual freedom. Secondly, limiting the use of arbitrary conditions that may appear in many contracts. ${ }^{18}$ Thirdly, enabling the injured party to minimize the losses sustained, which the party suffered as a result of the economic contractual imbalance involving the counterparty. ${ }^{19}$

\section{The Legal Basis for the Principle of Good Faith at the Stage of Negotiation}

Depending on the different prevailing legal systems, the comparative legal jurisprudence is still divided on the legal nature of the principle of good faith and its function in achieving contractual equilibrium at the pre-contracting phase. While the German legislature applied this principle as one of the requisite principles that govern and regulate the negotiation phase, ${ }^{20}$ which is similar to the position of the Principles of European Contract Law (PECL) which stipulates not to negotiate contrary to the requirements of good faith, ${ }^{21}$ the English jurists differed on the effectiveness of this principle in contractual relations. On the one hand, some of them did not deny the existence of this principle at the implementation phase. However, they denied its existence at the pre-contracting phase on the basis of the absence of a contractual relation during this phase and, thus, the

\footnotetext{
${ }^{14}$ Such as, inequality of bargaining power between parties during the contract negotiations phase, lack of information by a party in contrast with another, a defect of consent, or the manner in which the contract is concluded, as in the case of contracts of adhesion or model contracts.

${ }^{15}$ See Aryan, S.; Mirabbasi, B. (2016). The Good Faith Principle and Its Consequences in Pre-contractual Period: Comparative Study on English and French Law. Journal of Politics and Law 9(2), p 233.

${ }^{16}$ Such as, the position of German or French Jurists. See Cremades, B. M. (2012). Good Faith in International Arbitration. American University International Law Review 27(4), p 773. Besides that, the Jurists who formed the UNIDROIT Principles of International Commercial Contracts (PICC), 2016 Edition, or the Jurists who formed the Principles of European Contract Law (PECL).

${ }^{17}$ See Fayyad, M. (2014). Measures of the Principle of Good Faith in European Consumer Protection and Islamic Law, Comparative Analysis. Supra note, $\mathrm{p} 211$.

${ }^{18}$ Such as the Palestinian Law of Concerning Consumer Protection No. 21 of 2005 , which included a full chapter under the title of "Impartiality of Economic Transactions". See also article (2.1.15) of the UNIDROIT Principles of International Commercial Contracts (PICC), 2016 Edition.

${ }^{19}$ For example, the Palestinian legislature states in article 16 of the Palestinian Law of Insurance No. 20 of 2005: "1- in the event the insured conceals under an ill intention a matter or submits an incorrect statement in a manner that reduces the relevance of the risk insured against or leads to the change of its subject matter or in the event he or she violates by means of fraud of the satisfaction of what he or she has pledged to do, the insurer shall be entitled to request the annulment of the contract. It may also demand the payment of the due premiums prior to such request. 2- in case fraud or bad intention is dispelled, the insurer must upon request annul the contract and return to the insured the premiums which have been paid or return the amount which was not afforded in meeting a particular risk".

${ }^{20}$ The German legislature obliged each contracting party to respect the rights of the interests of the other party in paragraph 2 of article 241 of the Civil Code, which stated: "an obligation may also, depending on its contents, oblige each party to take account of the rights, legal interests and other interests of the other party". However, the German legislature extend this obligation to be applicable to the contractual negotiation stage, where the second paragraph of article 311 states: "an obligation with duties under section 241 (2) also comes into existence by: 1- the commencement of contract negotiations. ..". in addition to the stage of its implementation in accordance with article 242 "an obligor has a duty to perform according to the requirements of good faith, taking customary practice into consideration". Russi, L. (2009). Substance or mere technique a precis on good faith performance in England, France and Germany. Hanse Law Review 5(1), 21-32. Li, X. (2017). The Legal Status of Pre-contractual Liability: Contrasting Responses from German and English Law. National Taiwan University Law Review 12(1), p 133.

${ }^{21}$ Article 2: 301 of the PECL states: "1- a party is free to negotiate and is not liable for failure to reach an agreement. 2- however, a party who has negotiated or broken off negotiations contrary to good faith and fair dealing is liable for the losses caused to the other party. 3-it is contrary to good faith and fair dealing, in particular, for a party to enter into or continue negotiations with no real intention of reaching an agreement with the other party". Moreover, article (2.1.15) of UNIDROIT principles provided a similar duty, "1- a party is free to negotiate and is not liable for failure to reach an agreement. 2- however, a party who negotiates or breaks off negotiations in bad faith is liable for the losses caused to the other party. 3- it is bad faith, in particular, for a party to enter into or continue negotiations when intending not to reach an agreement with the other party". See Principles of European Contract Law, UNIDROIT Principles of International Commercial Contracts (PICC), 2016 Edition. Li, X. (2017). The legal Status of Pre-contractual Liability: Contrasting Responses from German and English Law. Supra note, p 139. Salazar Revuelta, M.; Herrera Bravo, R. (2017). Principia Iuris as Means of Harmonization and Unification of European Law through Historical-Comparative Methodology. GLOSSAE: European Journal of Legal History 14, p 848. Miller, A. D.; Perry, R. (2013). Good faith performance. Iowa Law Review 98(2), p 694.
} 
absence of any contractual obligations. On the other hand, many other English jurists denied the existence of this principle in the pre- and post-contract phase on the grounds that the national judge did not have the authority to check for the common intention of the contracting parties. ${ }^{22}$

This was clearly endorsed by the British House of Lords in 1992 in the well-known case of (Martin Walford v Charles Miles), which expressly states "there is no obligation to negotiate in good faith in contract theory in the British legal system". ${ }^{23}$ In 1994, however, the English legislature passed Act No. 3159/1994 on the unfair terms in consumer contracts regulations, which was amended by Act No. 2083/1999, which, implementing the EC Directive 93/13/EEC, ${ }^{24}$ article (5/1) of this Act, adopts the principle of good faith when the English legislature considered "a contractual term which has not been individually negotiated shall be regarded as unfair if, contrary to the requirement of good faith, it causes a significant imbalance in the parties' rights and obligations arising under the contract, to the detriment of the consumer". ${ }^{25}$

Furthermore, the British House of Lords, in 2002, acknowledged the existence of some applications of the principle of good faith in the famous case of Yeoman's Row Management (Ltd v Cobbe, and Thorner v Major in 2009) ${ }^{26}$ influenced by the evolution of the judgments of the American courts. ${ }^{27}$ Nevertheless, the British legislature still denies the absolute application of the principle of good faith to contractual obligations and limits it to a certain field of contracts as consumption contracts in accordance with EU directives. ${ }^{28}$

However, the position of the majority of the Civil Law Legal Systems approached the direction of the German legislature, since the pre-contracting phase is governed by two principles in the Civil Law Legal System: the principle of contractual freedom and the principle of good faith. ${ }^{29}$ Meanwhile, the main rule is that each party has the right to enter into negotiations and to continue or withdraw from them without any liability, since the principle of contractual freedom gives each party the right to contract or not, and as the phase of negotiations is only a phase of disclosure between the parties, an exchange of views, and a discussion of suggestions and a dialogue on the terms of the contract to be concluded, where the requisite terms of the contract have yet to be determined, and the parties have no firm intention to contract immediately. Thus, based on the fundamentals of freedom of the contract, each party may terminate the negotiations phase as a general rule as long as the principles of good faith and fair dealing are followed. ${ }^{30}$ This was taken by the French legislature in article 1112 of the new Civil Code, which was created by Decree N 131-2016 of 10 February 2016. ${ }^{31}$ Article 1112 states: "the commencement, continuation and breaking-off of pre-contractual negotiations are free from control. They

\footnotetext{
${ }^{22}$ Aryan, S.; Mirabbasi, B. (2016). The Good Faith Principle and Its Consequences in Pre-contractual Period: Comparative Study on English and French Law. Supra note, p 233-234. Perry, C. (2016). Good Faith in English and US Contract Law: Divergent Theories, Practical Similarities. Business Law International 17(1), p 27. Marsh, P. D. V. (1994). Comparative Contract Law: England France, Germany. Hampshire, England: Aldershot. P 178. Beautridge, J. (2016). Understanding Good Faith in the Context of Contractual Performance: Lessons to Learn from the German System. Anglo-German Law Journal 2, p 50.

${ }^{23}$ See van Erp, S. (1992). Good Faith: Concept Unworkable in Practice. Tilburg Foreign Law Review 1(3), p 217-226. Doris, M. (2014). Promising Options, Dead Ends and the Reform of Australian Contract Law. Legal Studies 34(1), p 38-39. Legrand, P. (2011). Foreign Law: Understanding Understanding. Journal of Comparative Law 6(2), p 98.

${ }^{24}$ The EC Directive 93/13/EEC on Unfair Terms in Consumer Contracts.

${ }^{25}$ The UK Unfair Terms in Consumer Contracts Regulations of 1999 (1999 SI 2083).

${ }^{26}$ For the case details see Hopkins, N. (2011). The Relevance of Context in Property Law: Case for Judicial Restraint. Legal Studies 31(2), p 177-180. Piska, N. (2009). Hopes, Expectations and Revocable Promises in Proprietary Estoppel. Modern Law Review 72(6), p 1002-1005.

${ }^{27}$ For the case details see Mee, J. (2009). The Limits of Proprietary Estoppel: Thorner major. Child and Family Law Quarterly 21(3), p 372-373. Piska, N. (2009). Hopes, Expectations and Revocable Promises in Proprietary Estoppel. Supra note, p 999-1002.

${ }^{28}$ Musy, A. M. (2001). The Good Faith Principle in Contract Law and the Precontractual Duty to Disclose: Comparative Analysis of New Differences in Legal Cultures. Global Jurist 1(1), [i]-21. P 10-12. Piers, M. (2011). Good Faith in English Law Could Rule Become Principle. Tulane European and Civil Law Forum 26, p 130-145. Krauss, O. (2015-2016). The Enforceability of Escalation Clauses Providing for Negotiations in Good Faith under English Law. McGill Journal of Dispute Resolution 2, 142-[ii]. P 157-158.

${ }^{29}$ Ghestin, J. (2007). La responsabilité délictuelle pour rupture abusive des pourparlers. JCP G, 155.

${ }^{30}$ See Deshayes, O., Genicon, T., \& Laithier, Y. M. (2016). Réforme du droit des contrats, du régime général et de la preuve des obligations: commentaire article par article. LexisNexis. p 75.

French Court of Cassation, Commercial Room, Public Sitting of Tuesday, 9 February 2016, No of Appeal: 14-15134. Retrieved from https://www.legifrance.gouv.fr/affichJuriJudi.do?oldAction=rechExpJuriJudi\&idTexte=JURITEXT000032057619\&fastReqId=649482122\& fastPos=12 visited on 20/7/2018.

${ }^{31}$ During the past decades, the French judiciary has played a major role in the development and modernization of the French legal system in a number of areas. This judicial role was manifested in the recent legislative reforms in the field of contracts, with the issuance of Decree $\mathrm{N}$ 131-2016 "Law of Contracts, the General Regime of Obligations, and Proof of Obligations". Estrella Faria, J. A. (2016). The Influence of the UNIDROIT Principles of International Commercial Contracts on National Laws. Uniform Law Review, 21(2-3), p 262. Sejean, M. (2016). The French Reform of Contracts: An Opportunity to Tie together the Community of Civil Lawyers. Louisiana Law Review 76(4), p 1153.
} 
must mandatorily satisfy the requirements of good faith". ${ }^{32}$

Moreover, article 1337 of the Italian Civil Code (approved by Royal Decree of March 16, 1942, No. 262, and as amended by Decree of December 7, 2016, No. 291) states under the section of negotiations and pre-contractual responsibility: "while carrying out the negotiations and the formation of contract, the parties must behave according to good faith". ${ }^{33}$ Therefore, the principle of contractual freedom remains as the general rule in the contractual negotiation phase while the principle of good faith constitutes a restraint that controls the conduct of parties during negotiations to prevent abuse. ${ }^{34}$

In reference to the provisions of the Palestinian Civil Code Draft, we find that it is devoid of any provisions governing the contractual negotiation phase or any provision imposing the obligation of behaving in good faith at this phase, where the Palestinian legislature made the first paragraph of article 148 of the PDCC clearly limited to obligating the contracting parties to implement the contract in good faith. ${ }^{35}$ However, this position is in conformity with the position of the French legislature in article 1134 of the French Civil Code before enacting the Decree N 131-2016 of 10 February $2016 .^{36}$

This provision (article 1134) did not prevent the French jurists and judges of the French Court of Cassation from dealing with the principle of good faith as a legal obligation also applicable to the pre-contracting phase, based on the tortious liability and, in particular, the provisions of articles $1382^{37}$ and $1383,{ }^{38}$ which are similar to the provisions of articles $179^{39}$ and $180^{40}$ of the Palestinian Civil Code Draft. And here lies the main question: Does relying on the theory of error (articles $179 \& 180$ ) of the Palestinian Civil Code Draft address the legislative shortcomings in the legislative remedy for the subject of good faith in preliminary negotiations? The answer to this question requires us to examine the terms of liability and the nature of compensation arising from the theory of error in the PDCC.

\subsection{The Liability Terms of the Pre-Contracting Phase}

Article 179 of the PDCC institutes a general rule that anyone "who has committed an act that caused 'damage' to another party is obliged to compensate, ${ }^{41}$ indicating the elements of tort liability ${ }^{42}$ namely, the commission of an act that results in damage where there must be a causal relationship between the act and the damage. ${ }^{43}$ Here, it

\footnotetext{
${ }^{32}$ The original text of article 1112 is: "l'initiative, le déroulement et la rupture des négociations précontractuelles sont libres. Ils doivent impérativement satisfaire aux exigences de la bonne foi".

${ }^{33}$ The original text of article 1337 is: "le parti, nello svolgimento delle trattative e nella formazione del contratto, devono comportarsi secondo buona fede". See Mato Pacin, M. (2015). Content Control of Standard Terms in Business-to-Business Contracts in Comparative and European Law. Cuadernos de Derecho Transnacional 7(2), p 236. Novoa, R. (2005). Culpa in Contrahendo: Comparative Law Study: Chilean Law and the United Nations Convention on Contracts for the International Sale of Goods (cisg). Arizona Journal of International and Comparative Law 22(3), p 586. Procida Mirabeli di Lauro, A. (2016). L'Obbligazione Come Rapporto Complesso. Revista Brasileira de Direito Civil 7, p 152. Febbrajo, T. (2016). Good Faith and Pre-Contractual Liability in Italy: Recent Developments in the Interpretation of Article 1337 of the Italian Civil Code. Italian Law Journal 2(2), p 292.

${ }^{34}$ See Deshayes, O., Genicon, T., \& Laithier, Y. M. (2016). Réforme du droit des contrats, du régime général et de la preuve des obligations: commentaire article par article. Supra note, $\mathrm{p} 75$.

${ }^{35}$ The first paragraph of article 148 of the PDCC states: "the contract shall be executed in accordance with what it has included and, in a manner, consistent with what is required by good faith".

${ }^{36}$ Article 1134 of the French Civil Code of 1804 states: "1- agreements lawfully entered into have the force of law for those who have made them. 2- they may be revoked only by their mutual consent, or for causes allowed by law. 3- they must be performed in good faith".

${ }^{37}$ Article 1382 of the French Civil Code of 1804 states: "any act whatever of man, which causes damage to another, obliges the one by whose fault it occurred, to compensate for it".

${ }^{38}$ Article 1383 of the French Civil Code of 1804 states: "everyone is liable for the damage he causes not only by his intentional act, but also by his negligent conduct or by his imprudence".

39 Article 179 of the PDCC states: "anyone who has committed an act that caused damage to others is obliged to compensate for it".

${ }^{40}$ Article 180 of the PDCC states: "1- a person is responsible for his/her harmful actions as long as he/she is in full possession of their senses. 2- if harm is inflicted upon another by a person who is not in full possession of their faculties, and there is not a person who is responsible for him, or it has proved difficult to get a compensation from the person responsible for the inflicted damage, then the judge is at will to force the person who inflicted the damage to pay a fair compensation keeping in mind the standing of each opponent".

${ }^{41}$ This rule is based on what is stated in the Islamic jurisprudence and the provisions of the Al-majallah Al-ahkam Al-adaliyyah, (The Ottoman Courts Manual) in the articles: Article 19 "injury may not be met by injury", article 20 "injury is removed". See the Official Explanatory of the Palestinian Civil Code Draft. Unpublished Manuscript. p 220.

${ }^{42}$ French Court of Cassation, Commercial Room, Public Sitting of Wednesday, June 27, 2018, No of Appeal: 16-26.360. Retrieved from https://www.legifrance.gouv.fr/affichJuriJudi.do?oldAction=rechExpJuriJudi\&idTexte=JURITEXT000037196607\&fastReqId=731895665\& fastPos=1 visited on 21/7/2018.

${ }^{43}$ See the Official Explanatory of the Palestinian Civil Code Draft. Unpublished Manuscript. p 220. Moreover, according to the provisions of articles 1112 and 1104 of the new French Decree N 131-2016 of 10 February 2016 which impose a legal obligation to negotiate in good faith,
} 
should be noted that: first, the text of the article 179 does not include an enumeration of harmful acts, which means that the Palestinian legislature preferred to leave the matter to the discretion of the judge. ${ }^{44}$ Second, cutting off negotiations cannot in itself constitute a harmful act that requires tort liability, but there must be a harmful act during this phase bearing liability. ${ }^{45}$ The Commercial Room of the French Court of Cassation ruled in its decision of 26 November 2003 that: "contractual freedom includes the right to sever the negotiations. Nevertheless, this freedom is restricted in the case of abuse of the right to sever the negotiations, such as, violating the trust of the other party, such behaviour is contrary to contractual good faith". ${ }^{46}$ The French Court of Cassation expressed this in several terms: "a breach of negotiation without legitimate justification", 47 "wrongful breach", 48 "abusive breach" 49 and other similar expressions.

Third, the victim of abusive breach of the negotiations must possess evidence of the fault of the other party that caused the damage. ${ }^{50}$ Therefore, the French judiciary has not established any presumption that the person who is interrupting the negotiations is mistaken, since the error is not in the breach of the negotiations itself, but in the circumstances surrounding the process of breaching the negotiations, as a violation of the principle of good faith or the duty of impartiality in dealing, ${ }^{51}$ as in the case of a party entering negotiations without having a real

it makes the liability for the breaching of pre-contracting negotiations a tortious liability, even if this is not explicitly expressed. However, this is the same trend that the French judiciary has been pursuing for a long time. Article 1112 "1-the commencement, continuation and breaking-off of precontractual negotiations are free from control. They must mandatorily satisfy the requirements of good faith. 2- in case of fault committed during the negotiations, the reparation of the resulting loss is not calculated so as to compensate the loss of benefits which were expected from the contract that was not concluded". Article 1104 "1- contracts must be negotiated, formed and performed in good faith. 2- this provision is a matter of public policy". See French Court of Cassation, Civil Room 1, Public Sitting of Wednesday, January 26, 2011, No of Appeal: 10-10115. Retrieved from

https://www.legifrance.gouv.fr/affichJuriJudi.do?oldAction=rechExpJuriJudi\&idTexte=JURITEXT000023496233\&fastReqId=1786260969 $\&$ fastPos $=1$ visited on $21 / 7 / 2018$

${ }^{44}$ Furthermore, the Official Explanatory did not include an enumeration of harmful acts. See the Official Explanatory of the Palestinian Civil Code Draft. Unpublished Manuscript. p 220.

45 "le seul refus de poursuivre la vente ne suffit pas à caractériser une faute ; que la liberté contractuelle implique celle de rompre les pourparlers, liberté qui n'est limitée que par l'abus du droit de rompre qui est une faute caractérisée par le fait de tromper la confiance du partenaire; que la cour d'appel, qui n'a relevé aucun élément à la charge de la société Blanc Colombe de nature à caractériser un tel comportement, contraire à la bonne foi contractuelle, a privé sa décision de toute base légale au regard de l'article 1382 du code civil". French Court of Cassation, Civil Room 1, Public Sitting of Wednesday, 14 December 2016, No of Appeal: 15-25352. Retrieved from

https://www.legifrance.gouv.fr/affichJuriJudi.do?oldAction=rechExpJuriJudi\&idTexte=JURITEXT000033631635\&fastReqId=1809616963 \&fastPos $=2$ visited on 21/7/2018.

46 "la liberté contractuelle implique celle de rompre les pourparlers, liberté qui n'est limitée que par l'abus du droit de rompre qui est une faute caractérisée par le fait de tromper la confiance du partenaire; que la cour d'appel, qui n'a relevé aucun élément à la charge du cédant de nature à caractériser un tel comportement, contraire à la bonne foi contractuelle, a privé sa décision de toute base légale au regard des articles 1382 et 1383 du Code civil". French Court of Cassation, Commercial Room, Public Sitting of Wednesday 26 November 2003, No of Appeal: 00-10243 00-10949. Retrieved from

https://www.legifrance.gouv.fr/affichJuriJudi.do?oldAction=rechExpJuriJudi\&idTexte=JURITEXT000007049778\& fastReqId=1984111551 $\&$ fastPos $=3$ visited on $21 / 7 / 2018$.

See French Court of Cassation, Civil Room 3, Public Sitting of Thursday 30 November 2017, No of Appeal: 14-20449. Retrieved from https://www.legifrance.gouv.fr/affichJuriJudi.do?oldAction=rechExpJuriJudi\&idTexte=JURITEXT000036138922\&fastReqId=1680998632 $\&$ fastPos $=1$ visited on 21/7/2018

47 "rupture dépourvue de motif légitime". French Court of Cassation, Commercial Room, Public Sitting of Tuesday, 5 December 2006, No of Appeal: 05-12926. Retrieved from

https://www.legifrance.gouv.fr/affichJuriJudi.do?oldAction=rechExpJuriJudi\&idTexte=JURITEXT000007513872\&fastReqId=1787661435 \&fastPos $=1$ visited on 21/7/2018

48 "rupture fautive". French Court of Cassation, Commercial Room, Public Sitting of Tuesday, 18 October 2016, No of Appeal: 14-27212. Retrieved from

https://www.legifrance.gouv.fr/affichJuriJudi.do?oldAction=rechExpJuriJudi\&idTexte=JURITEXT000033297550\&fastReqId=1780363868 $\&$ fastPos $=1$ visited on 12/7/2018

49 "rupture abusive". French Court of Cassation, Commercial Room, Public Sitting of Wednesday, 13 June 2018, No of Appeal: 17-12038. Retrieved from

https://www.legifrance.gouv.fr/affichJuriJudi.do?oldAction=rechExpJuriJudi\&idTexte=JURITEXT000037135742\&fastReqId=903583666\& fastPos $=1$ visited on 21/7/2018.

${ }^{50}$ French Court of Cassation, Commercial Room, Public Sitting of Tuesday, 13 November 2001, No of Appeal: 99-12046. Retrieved from https://www.legifrance.gouv.fr/affichJuriJudi.do?oldAction=rechExpJuriJudi\&idTexte=JURITEXT000007432137\& fastReqId=307382651\& fastPos $=1$ visited on 21/7/2018.

${ }^{51}$ French Court of Cassation, Civil Room 1, Public Sitting of Wednesday, 1 June 2016, No of Appeal: 15-13221. Retrieved from https://www.legifrance.gouv.fr/affichJuriJudi.do?oldAction=rechExpJuriJudi\&idTexte=JURITEXT000032635842\&fastReqId=883482089\& fastPos $=3$ visited on 21/7/2018 
intention to contract, ${ }^{52}$ or with the intention to disclose confidential information to the other party, ${ }^{53}$ conducting the negotiations knowing it will not lead to the conclusion of the contract, ${ }^{54}$ negotiating in bad faith or in a trivial manner, ${ }^{55}$ negotiating with the intention of causing damage to others ${ }^{56}$ breaching advanced negotiations without legitimate justification, ${ }^{57}$ even without the intention of harming ${ }^{58}$ or providing pseudo information about the existence of parallel negotiations, or deceiving the other party into believing that there are no parallel negotiations contrary to reality ${ }^{59}$ where the Commercial Room of the French Court of Cassation in 26/11/2003 ruled that "parallel negotiations with a third party do not in themselves constitute a harmful action that imposes liability, unless it was done with the intention of harm or it was accompanied by fraudulent practices" ${ }^{60}$ Thus, the parallel negotiation does not comprise in itself a violation of the principle of good faith. ${ }^{61}$

In contrast, the cessation or breaching of negotiations is not abusive if it is based on a legitimate cause or

French Court of Cassation, Civil Room 1, Public Sitting of Wednesday, 1 June 2011, No of Appeal: 10-30205. Retrieved from

https://www.legifrance.gouv.fr/affichJuriJudi.do?oldAction=rechExpJuriJudi\&idTexte=JURITEXT000024117411\&fastReqId=551790077\& fastPos=15 visited on 21/7/2018. See Giliker, P. (2003). role for tort in pre-contractual negotiations an examination of english, french, and canadian law. International and Comparative Law Quarterly 52(Part 4), p 981. Rosher, P. (2016). French contract law reform. Business Law International 17(1), p 69-70.

52 "que commet une faute de nature à engager sa responsabilité délictuelle celui qui entreprend une négociation sans intention réelle de contracter et rompt sans raison légitime. .." See French Court of Cassation, Commercial room, Public Sitting of Tuesday 17 March 2009, No of Appeal: 08-12830. Retrieved from

https://www.legifrance.gouv.fr/affichJuriJudi.do?oldAction=rechExpJuriJudi\&idTexte=JURITEXT000020422993\&fastReqId=1485572155 \&fastPos=1 visited on 21/7/2018. See Szalma, J. (2010). Liability for conducting negotiations in bath faith. Zbornik Radova 44(3), p 71.

${ }^{53}$ Such as getting his financial status, future plans or technical knowledge. French Court of Cassation, Commercial Room, Public Sitting of Tuesday 15 December 2015, No of Appeal: 14-11500. Retrieved from

https://www.legifrance.gouv.fr/affichJuriJudi.do?oldAction=rechExpJuriJudi\&idTexte=JURITEXT000031652185\&fastReqId=1291960490 $\&$ fastPos $=3$ visited on 22/7/2018. Besides that, the second paragraph of article (2.1.15) of UNIDROIT principles states: "however, a party who negotiates or breaks off negotiations in bad faith is liable for the losses caused to the other party". In the same context, see the second paragraph of article (2:301) of the Principles of European Contract Law.

${ }^{54}$ French Court of Cassation, Commercial Room, 18 January 2002, N of Appeal: 99- 16.488.

55 "la liberté contractuelle implique celle de rompre les pourparlers, liberté qui n'est limitée que par l'abus du droit de rompre qui est une faute caractérisée par le fait de tromper la confiance du partenaire. ..”. French Court of Cassation, Civil Room, Public Sitting of Thursday 30 November 2017, No of Appeal: 14-20449. Retrieved from

https://www.legifrance.gouv.fr/affichJuriJudi.do?oldAction=rechExpJuriJudi\&idTexte=JURITEXT000036138922\&fastReqId=1383574738 \&fastPos=31 visited on 22/7/2108. French Court of Cassation, Civil Room 3, Public Sitting of Thursday 22 June 2017, No of Appeal: 16-17946. Retrieved from

https://www.legifrance.gouv.fr/affichJuriJudi.do?oldAction=rechExpJuriJudi\&idTexte=JURITEXT000035005152\&fastReqId=969675883\& fastPos $=50$ visited on 22/7/2018. See Aryan, S.; Mirabbasi, B. (2016). The Good Faith Principle and Its Consequences in Pre-contractual Period: Comparative Study on English and French Law. Supra note, p 242.

${ }^{56}$ French Court of Cassation, Civil Room 3, Public Sitting of Thursday, 16 November 2017, No of Appeal: 15-12268. Retrieved from https://www.legifrance.gouv.fr/affichJuriJudi.do?oldAction=rechExpJuriJudi\&idTexte=JURITEXT000036056240\&fastReqId=1383574738 $\&$ fastPos $=33$ visited on 22/7/2018. French Court of Cassation, Civil Room 1, Public Sitting of Wednesday 30 November 2016, No of Appeal: 14-18818. Retrieved from

https://www.legifrance.gouv.fr/affichJuriJudi.do?oldAction=rechExpJuriJudi\&idTexte=JURITEXT000033527603\&fastReqId=969675883\& fastPos $=81$ visited on 22/7/2018.

${ }^{57}$ French Court of Cassation, Civil Room 3, Public Sitting of Thursday 15 June 2017, No of Appeal: 16-15916. Retrieved from https://www.legifrance.gouv.fr/affichJuriJudi.do?oldAction=rechExpJuriJudi\&idTexte=JURITEXT000034962442\&fastReqId=318284979\& fastPos=71 visited on 22/7/2018.

${ }^{58}$ French Court of Cassation, Commercial Room, Public Sitting of Wednesday, 13 September 2017, No of Appeal: 15-12178. Retrieved from https://www.legifrance.gouv.fr/affichJuriJudi.do?oldAction=rechExpJuriJudi\&idTexte=JURITEXT000035573369\&fastReqId=1971868830 $\&$ fastPos $=40$ visited on 22/7/2018.

${ }^{59}$ See Rosher, P. (2016). French contract law reform. Supra note, p 69-70.

60 "mais attendu que le simple fait de contracter, même en connaissance de cause, avec une personne ayant engagé des pourparlers avec un tiers ne constitue pas, en lui-même et sauf s'il est dicté par l'intention de nuire ou s'accompagne de manoeuvres frauduleuses, une faute de nature à engager la responsabilité de son auteur. ..”. See the French Court of Cassation, Commercial room, Public Sitting of Wednesday 26 November 2003, No of Appeal: 00-10243 00-10949. Retrieved from

https://www.legifrance.gouv.fr/affichJuriJudi.do?oldAction=rechExpJuriJudi\&idTexte=JURITEXT000007049778\& fastReqId=313401159\& fastPos=1 visited on 23/7/2018.

${ }^{61}$ Rosher, P. (2015). New developments in the impending reform of french contract law. International Business Law Journal $2015(6)$, p 505. Abell, M.; Hobbs, V. (2014). Duty of good faith in franchise agreements a comparative study of the civil and common law approaches in the eu. International Journal of Franchising Law 12(1), p 28-29. 
justification. ${ }^{62}$ Nevertheless, the French Court of Cassation has not provided a specific definition or concept of legitimate justification, but some rules and regulations can be drawn up for the legitimate justification through some of its judicial decisions:

A. The judge must consider before deciding on a party the liability for the abusive breach of negotiations, and the extent to which there is a legitimate reason or justification to breach the negotiations. ${ }^{63}$

B. Breaching negotiation even if it is at an advanced stage, can have a legitimate reason or justification. In this context, the Commercial Room of the French Court of Cassation ruled in 12 January 1999 that: "since the parties agreed on the desirability of a partnership; however, they had not yet defined the price or the objectives, and besides that the development plan was not drafted, nor the conclusion of the shareholder pact, ... and there were many obstacles that had to be crossed before reaching a final agreement, especially that the outcome of the project was closely linked to the economic situation of the moment. They cannot therefore claim that the negotiations were about to succeed and that their abrupt termination was at fault when it came at a time when the parties were still assessing the risks and chances of the contract. Therefore, they are free to question everything without having to provide a legitimate justification". ${ }^{64}$

C. The cessation or breaching of negotiations cannot be qualified as illegitimate or abusive, as long as the principle of good faith is respected ${ }^{65}$ and free from fraudulent maneuvers or dishonest behaviour. ${ }^{66}$

Fourth: Article 179 of the PDCC begins with: "anyone who has committed an act. ..", which means that it does not cover the non-action (refrain from doing an act) which entails damage. In other words, the text deals with the positive act without the negative act, while the tortious liability ensues in both cases of a positive and negative act if it causes damage. Therefore, the Palestinian legislature must amend the text of article 179 to include both acts as follows: "all damage affected by someone against another obligates the person who affected the damage to compensate the other". 67 Thus, the elements of tortious liability are the commission of an act or

${ }^{62}$ The principle of good faith obliged the parties to conduct the negotiations in an impartial manner. "un simple accord de principe oblige seulement les parties à poursuivre les négociations de bonne foi et ne peut emporter un engagement ferme et définitif de conclure le contrat projeté. ..”. See French Court of Cassation, Civil Room 3, Public Sitting of Thursday 23 November 2017, No of Appeal: 16-21127. Retrieved from

https://www.legifrance.gouv.fr/affichJuriJudi.do?oldAction=rechExpJuriJudi\&idTexte=JURITEXT000036095021\&fastReqId=538796450\& fastPos $=3$ visited on 23/7/2018.

In the same context, French Court of Cassation, Commercial room, Public Sitting of Tuesday, 9 February 2016, No of Appeal: 14-15134. Retrieved from

https://www.legifrance.gouv.fr/affichJuriJudi.do?oldAction=rechExpJuriJudi\&idTexte=JURITEXT000032057619\&fastReqId=649482122\& fastPos=12 visited on 23/7/2018.

See Lou, S. (2017). Sino-philippine arbitration on south china sea disputes: perspective from the principle of good faith. China Oceans Law Review 2017(1), p 198.

${ }^{63}$ See French Court of Cassation, Commercial Room, Public Sitting of Tuesday, 7 March 2006, No of Appeal: 04-17177. Retrieved from https://www.legifrance.gouv.fr/affichJuriJudi.do?oldAction=rechExpJuriJudi\&idTexte=JURITEXT000007496851\&fastReqId=1326058169 \&fastPos $=121$ visited on 23/7/2018.

64 “mais attendu que l'arrêt relève notamment qu'au moment où la rupture a été signifiée, le 11 septembre 1990, les négociations qui n'étaient engagées que depuis le mois de mars précédent étaient très loin d'aboutir, puisque si les parties étaient bien d'accord sur l'opportunité d'un partenariat, elles n'avaient encore défini ni le prix, ni les objectifs, que le plan de développement n'était pas ébauché, que ni la conclusion du pacte d'actionnaire, ni la possibilité pour la Compagnie La Hénin de contrôler les sociétés détenues par les consorts Z... n'avaient été discutées et que rien n'avait été décidé non plus en ce qui concerne les SCI et la vente éventuelle de leurs biens; que les consorts Z..., qui sont des professionnels avertis et qui ne pouvaient ignorer qu'à ce stade de nombreux obstacles restaient à franchir avant de parvenir à un accord définitif ni surtout que l'aboutissement du projet était étroitement lié à la conjoncture économique du moment, ne sauraient donc prétendre que les négociations étaient sur le point d'aboutir et que leur rupture brutale a été fautive alors qu'elle est intervenue à un moment où les parties en étaient encore à évaluer les risques et les chances du contrat envisagé sans d'ailleurs disposer de tous les éléments nécessaires à la décision et qu'elles étaient donc libres de tout remettre en cause sans avoir à fournir de justification légitime. ..". See the French Court of Cassation, Commercial Room, Public Sitting of Tuesday, 12 January 1999, No of appeal: 96-14604. Retrieved from

https://www.legifrance.gouv.fr/affichJuriJudi.do?oldAction=rechExpJuriJudi\&idTexte=JURITEXT000007399722\& fastReqId=1288383485 $\&$ fastPos $=10$ visited on 23/7/2018.

${ }^{65}$ French Court of Cassation, Civil Room 3, Public Sitting of Wednesday, 14 June 2000, No of Appeal: 98-22131. Retrieved from https://www.legifrance.gouv.fr/affichJuriJudi.do?oldAction=rechExpJuriJudi\&idTexte=JURITEXT000007617232\&fastReqId=1456704144 $\&$ fastPos $=270$ visited on 23/7/2018.

${ }^{66}$ French Court of Cassation, Commercial Room, Public Sitting of Tuesday 20 November 2007, No of Appeal: 06-20332. Retrieved from https://www.legifrance.gouv.fr/affichJuriJudi.do?oldAction=rechExpJuriJudi\&idTexte=JURITEXT000007627661\&fastReqId=157743782\& fastPos $=2$ visited on 23/7/2018.

${ }^{67}$ This was also the minority opinion of the drafters of the Palestinian Civil Code Project, which is corresponding by article 256 of the Jordanian Civil Code. See the Official Explanatory of the Palestinian Civil Code Draft. Unpublished Manuscript. p 220. 
non-act, which results in damage, and there must be a causal relationship between the act and the damage. ${ }^{68}$

Fifth, the Palestinian legislature structured the tortious liability on the basis of the damage idea (the objective theory) of tort liability, ${ }^{69}$ contrary to what the French legislature has embraced in the text of article 1382 of the French Civil Code of 1804 by adopting the error idea (the personal theory) as a basis for tort liability. ${ }^{70}$ However, the French legislature retracted that and adopted the objective theory for tort liability. ${ }^{71}$ Accordingly, the Palestinian legislature did well, since the damage can happen without error from anyone, so who will endure the damage? The wounded party which has no part in causing the damage? Of course, it must be borne by the one who produced a dangerous situation which ultimately caused the damage. ${ }^{72}$

Notwithstanding this, the text of article 180 of the PDCC makes the standard of liability the age of perception, where the first paragraph of article 180 states: "a person is responsible for his/her harmful actions as long as he/she is in full possession of their senses". This contradicts what was stated in article 179, as the Palestinian legislature returns to the idea of error as a basis for tort liability. In my opinion as a researcher, I consider that the text of article 179 is sufficient to determine the basis of tort liability on the basis of the notion of damage and to dispense with the mention of article $180^{73}$ in order to avoid the contradiction between the texts of the two articles.

\subsection{Consequential Compensation for Breaching Negotiations in the Pre-Contracting Phase}

Article 186 of the Palestinian Civil Code Draft provides the basis for compensation where it states: "in all cases, the compensation shall be assessed on the basis of the amount of harm suffered by the victim, together with loss of profit, provided that it is a natural result of the harmful act". ${ }^{74}$ However, the second paragraph of article 189 of the PDCC establishes a general rule that: "the court may, according to the circumstances and upon the application of the victim, order that the plaintiff be restored to his former position, and he may also order that a specific act connected with the harmful act be performed". ${ }^{75}$ The Palestinian legislature thus establishes a general rule of in kind-implementation (exécution en nature) as an essential rule (second paragraph of article 189), which must be adopted whenever possible with a view to bringing the parties back to the situation they were in before the harmful act of breaching the negotiations. ${ }^{76}$

The obligation to negotiate in good faith does not obligate the parties to conclude the desired contract. Rather, they are required to negotiate in preparation for its conclusion, taking into account the principle of good faith in the conduct of the negotiations. In addition, the enforcement of the principle of in-kind implementation means that the negotiation's parties must pursue the negotiations in order to achieve the final contract by force is contrary to the principle of contractual freedom. Even if in-kind implementation is possible and not cumbersome for the reluctant negotiator, forcing him to negotiate violates his personal freedom, ${ }^{77}$ besides that, it will not be useful because negotiations will inevitably fail. In this sense, the French judiciary has turned to accentuate that

\footnotetext{
${ }^{68}$ According to our suggestion which is based on the minority opinion of the drafters of the Palestinian Civil Code Project.

${ }^{69}$ See the Official Explanatory of the Palestinian Civil Code Draft. Unpublished Manuscript. p 216.

${ }^{70}$ See the Official Explanatory of the Palestinian Civil Code Draft. Unpublished Manuscript. p 215.

${ }^{71}$ See the Official Explanatory of the Palestinian Civil Code Draft. Unpublished Manuscript. p 216.

${ }^{72}$ The Palestinian legislature built this approach based on what is stated in the Islamic jurisprudence and the provisions of the AL-MAJALLA AL- AHKAM AL-ADALIYYAH, (The Ottoman Courts Manual) in article 87 of the "disadvantage is an obligation accompanying enjoyment. That is to say, a person who enjoys a thing must submit to the disadvantages attaching thereto".

${ }^{73}$ This was also the minority opinion of the drafters of the Palestinian Civil Code Project. See the Official Explanatory of the Palestinian Civil Code Draft. Unpublished Manuscript. p 217.

${ }^{74}$ The French legislature approved what has been established by the French judiciary on compensation for the abusive breaching of pre-contracting negotiations, which were limited to compensation for the actual damage caused to the victim, article 1112 of the French Decree N 131-2016 of 10 February 2016 states: "in case of fault committed during the negotiations, the reparation of the resulting loss is not calculated so as to compensate the loss of benefits which were expected from the contract that was not concluded".

75 Article 189 of the PDCC states: "1- the compensation shall be assessed in money. 2- the court may, according to the circumstances and upon the application of the victim, order that the plaintiff be restored to his former position, and he may also order that a specific act connected with the harmful act be performed. 3- the compensation may be made payable by instalments or by a regular income, and in those events the obligor may be ordered to provide a guarantee assessed by the court".

${ }^{76}$ This article is based on what the Palestinian legislature has ruled in article 225 of the PDCC states: "1- an obligor shall, after being given notice, be compelled to discharge his obligation by way of specific performance, if that is possible; 2- provided that if specific performance would be oppressive for the obligor, the court may, upon the application of the obligor, restrict the right of the obligee to a monetary substitute unless that would cause him serious loss".

${ }^{77}$ Schmidt-Szalewski, J. (2000). La force obligatoire à 1 'épreuve des avant-contrats. Paris, France: Dalloz. p 32.
} 
the principle of contractual freedom does not oblige the parties to conclude the desired contracts. ${ }^{78}$ Thus, in-kind implementation is improbable at the negotiating phase, but the actual issue arises mainly about the loss of a real chance to contract. ${ }^{79}$ In this regard, the Brussels Commercial Court ruled in June, 241985 that "it is impossible to implement in-kind. However, it asserted that what was lost was a chance to contract rather than the contract itself. $^{80}$ In sum, in-kind implementation is totally excluded in all cases where the parties are at the phase of negotiation and, therefore, the injured party in this phase can only resort to request compensation. ${ }^{81}$

Therefore, article 237 of the PDCC declares that: "if it is impossible for an obligor to give specific performance of an obligation, he shall be ordered to pay compensation for non-performance of his obligation, unless it is proved that the impossibility of performance arose out of an external cause in which the obligor played no part. The same shall apply in the event that the obligor defaults in the performance of his obligation". In this regard, the compensation shall be estimated in money, which should include the amount of harm suffered by the victim and loss of profit as stated in article 186 above. Furthermore, compensatory damages shall also include the compensation for moral damage. ${ }^{82}$ All of these are estimated by the court, ${ }^{83}$ in case that the parties have not specified in advance in the negotiating agreement or in a subsequent agreement the amount of the compensation. ${ }^{84}$ However, this agreement is not considered if negotiations fail with neither party being at fault. ${ }^{85}$ Nevertheless, we will limit our research to the most substantial damage caused by the cessation or breaching of negotiations: lost time, negotiating expenses, lost profits and loss of chance.

\subsubsection{Compensation of Wasted Time in Negotiation}

The loss of time from the damages normally anticipated in the negotiations should be compensated for whenever proof is there, ${ }^{86}$ where the French Court of Cassation ruled in a famous judgment, which highlighted the subject of compensation for the loss of time and summarized the facts as such: a couple announced their desire to accept an offer of a property for sale. Then, they requested an extension of the acceptance period so that they can finance the purchase; however, three months later, they expressed a firm will that they did not want to purchase the property. As a result of this, the owner insisted that the rejection came too late, and demanded compensation for the loss of time. The Court of Cassation has debased the decision of the judges of the subject for rejecting the request, based on the explanation that the judges of the subject did not consider that what happened has prevented the owner from otherwise dealing with his property during that time, ${ }^{87}$ knowing that prolongation of negotiations took place with the couple knowing that they will not buy and as such the contract would not be concluded. ${ }^{88}$ In other words, breaching off of the negotiations without relying on a serious or objective justification, despite the fact that they have taken a long time, will cause harm to the other party by wasting its

\footnotetext{
${ }^{78}$ See Deshayes, O., Genicon, T., \& Laithier, Y. M. (2016). Réforme du droit des contrats, du régime général et de la preuve des obligations: commentaire article par article. Supra note, p 75. See also, French Court of Cassation, Civil Room 1, Public Sitting of Wednesday, 14 December 2016, No of Appeal: 15-25352. French Court of Cassation, Commercial Room, Public Sitting of Wednesday 26 November 2003, No of Appeal: 00-10243 00-10949. French Court of Cassation, Civil Room, Public Sitting of Thursday 30 November 2017, No of Appeal: 14-20449. All these provisions were referred to earlier.

${ }^{79}$ See Jamal, M. (2002). The Willingness of Contracting. Beirut, Lebanon: Al-Halabi Legal Publications. p 246. Saleh, A. A. (2011). Negotiations in International Commercial Contracts. Supra note, $\mathrm{p} 760$.

${ }^{80}$ See Lutfi, H. M. (1995). Civil Responsibility in the Negotiation Phase, A Study in Egyptian and French Law. Cairo, Egypt: Al-Nasr Al-Dahabieh. p 85.

${ }^{81}$ See Saleh, A. A. (2011). Negotiations in International Commercial Contracts. Supra note, p 760.

${ }^{82}$ The third paragraph of article 239 of the PDCC states that: "the compensation shall also include moral damage, in which case it shall not be transferred to third parties unless its amount is determined by virtue of an agreement or by a final judgment".

${ }^{83}$ The first paragraph of article 239 of PDCC states: "if compensation is not determined in the contract, the court shall determine it. ..".

${ }^{84}$ Article 240 of the PDCC states: "the contracting parties may fix the amount of compensation in advance by making a provision therefore in the contract or in a subsequent agreement, subject to the provisions of the law".

${ }^{85}$ See Terré, F., Simler, P., \& Lequette, Y. (2002). Droit civil, Les obligations. Paris, France: Dalloz. p185.

${ }^{86}$ Tourneau, P. L. (1998). La rupture des négociations. Revue Trimestrielle de. $\mathrm{p} 489$.

${ }^{87}$ See the French Court of Cassation, Civil Room 1, Public Sitting of Wednesday, 19 January 1977, No of Appeal: 75-14096. Retrieved from https://www.legifrance.gouv.fr/affichJuriJudi.do?oldAction=rechExpJuriJudi\&idTexte=JURITEXT000006998645\& fastReqId=1530491333 $\&$ fastPos $=7$ visited on $27 / 7 / 2018$.

88 "The procrastination and lies of Mr. Bouly have resulted in a loss of time. . .". See the French Court of Cassation, Civil Room 1, Public Sitting of Tuesday, 9 July 1991, No of Appeal: 89-19931. Retrieved from

https://www.legifrance.gouv.fr/affichJuriJudi.do?oldAction=rechExpJuriJudi\&idTexte=JURITEXT000007134780\&fastReqId=1107460832 \&fastPos $=46$ visited on 27/7/2018.
} 
time ${ }^{89}$ which it should be compensated for.

However, the determination of compensation for loss of time is very intractable, this is due to the absence of substantial elements based on which to determine the amount of compensation resulting from the loss of time which makes the compensation for a loss of time an estimate, ${ }^{90}$ since the judge is the one who assesses the compensation for loss of time depending on the rules of justice and to the extent necessary to redress the damage suffered by the injured party, ${ }^{91}$ as the loss of time falls within the actual damage suffered by the injured party. ${ }^{92}$

\subsubsection{Compensation of Negotiating Expenses}

The negotiated expenses are defined as the expenditures spent by the negotiator for negotiations such as preparation expenses for the contract, ${ }^{93}$ technical studies, ${ }^{94}$ experts and consultants' reports, travel and accommodation expenses, ${ }^{95}$ etc. ${ }^{96}$ Such expenditures are an actual loss to the injured negotiator and must therefore be borne by the negotiator responsible for breaching the negotiations without an objective justification, which is considered as a breach of the principle that negotiations must be conducted in good faith.

In this regard, the French Court of Cassation decided that: the injury suffered by the Factum (finance company) is limited to the costs incurred by the negotiation and those of the preliminary studies. ${ }^{97}$ However, in order for the injured negotiator to claim compensation for such expenses, there must be a causal relationship between these expenses and the negotiation process that ended in failure. ${ }^{98}$ Besides that, such expenditures should not be excessive and unconscionable, since the negotiator is only responsible for reasonable expenses. Accordingly, the French Court of Cassation has settled that: "only the costs incurred by the person suffering the wrongful breach

${ }^{89}$ Melhem, H. S. (2010). Negotiating Contracts Through the Internet. Nahrain University Journal 13(2), p 94. See French Court of Cassation, Civil Room 3, Public Sitting of Thursday, February 18, 2016, No of Appeal: 15-12706. Retrieved from

https://www.legifrance.gouv.fr/affichJuriJudi.do?oldAction=rechExpJuriJudi\&idTexte=JURITEXT000032086870\&fastReqId=576682998\& fastPos=18 visited on 28/7/2018.

French Court of Cassation, Civil Room 3, Public Sitting of Thursday, February 18, 2016, No of Appeal: 15-12714. Retrieved from

https://www.legifrance.gouv.fr/affichJuriJudi.do?oldAction=rechExpJuriJudi\&idTexte=JURITEXT000032087203\&fastReqId=804351739\& fastPos=21 visited on 28/7/2018.

French Court of Cassation, Civil Room 3, Public Sitting of Tuesday 8 December 2009, No of Appeal: 08-18920. Retrieved from https://www.legifrance.gouv.fr/affichJuriJudi.do?oldAction=rechExpJuriJudi\&idTexte=JURITEXT000021475246\&fastReqId=804351739\& fastPos=41 visited on 28/7/2018.

${ }^{90}$ See Abdellah, K. R. (2000). Negotiate the Contract. Cairo, Egypt: Dar Alnahdah Alearabia. p 625.

${ }^{91}$ See the Official Explanatory of the Palestinian Civil Code Draft. Unpublished Manuscript. p 282.

${ }^{92}$ See article 186 of the PDCC.

${ }^{93}$ French Court of Cassation, Commercial Room, Public Sitting of Wednesday 26 November 2003, No of Appeal: 00-10243 00-10949. Retrieved from

https://www.legifrance.gouv.fr/affichJuriJudi.do?oldAction=rechExpJuriJudi\&idTexte=JURITEXT000007049778\&fastReqId=198411155 $\&$ fastPos $=3$ visited on 28/7/2018.

${ }^{94}$ The French Court of Cassation decided that "the company could only claim compensation for the costs incurred by the negotiation and the duly proven preliminary studies. ..". French Court of Cassation, Civil Room 3, Public Sitting of Tuesday, 7 July 2015, No of Appeal: 14-20536. Retrieved from

https://www.legifrance.gouv.fr/affichJuriJudi.do?oldAction=rechExpJuriJudi\&idTexte=JURITEXT000030878679\&fastReqId=153431856\& fastPos $=20$ visited on 28/7/2018.

${ }^{95}$ The damages in this decision appears in the travel and accommodation expenses. French Court of Cassation, Commercial Room, Public Sitting of Monday, 20 March 1972, No of Appeal: 70-14154. Retrieved from

https://www.legifrance.gouv.fr/affichJuriJudi.do?oldAction=rechExpJuriJudi\&idTexte=JURITEXT000006986985\&fastReqId=962939768\& fastPos $=4$ visited on 28/7/2018.

${ }^{96}$ Al-arabii, B. (2011). Problems of the Pre-contracting Phase in Light of Algerian Civil Code. Algeria, Algeria: Diwan Almatbueat Aljamieia. p 204.

${ }^{97}$ See the French Court of Cassation, Commercial Room, Public Sitting of Wednesday, 27 September 2017, No of Appeal: 15-15820. Retrieved from

https://www.legifrance.gouv.fr/affichJuriJudi.do?oldAction=rechExpJuriJudi\&idTexte=JURITEXT000035682907\&fastReqId=1943252746 $\&$ fastPos $=4$ visited on 28/7/2018.

${ }^{98}$ See the French Court of Cassation, Commercial Room, Public Sitting of Tuesday, 18 January 2011, No of Appeal: 09-14617. Retrieved from https://www.legifrance.gouv.fr/affichJuriJudi.do?oldAction=rechExpJuriJudi\&idTexte=JURITEXT000023464963\&fastReqId=1338289966 \&fastPos $=41$ visited on 28/7/2018.

French Court of Cassation, Commercial Room, Public Sitting of Tuesday 20 November 2007, No of Appeal: 06-17289. Retrieved from https://www.legifrance.gouv.fr/affichJuriJudi.do?oldAction=rechExpJuriJudi\&idTexte=JURITEXT000007626821\&fastReqId=1338289966 $\&$ fastPos $=57$ visited on $28 / 7 / 2018$. 
of pre-contractual negotiations constitute compensable damage; ${ }^{99}$ as such, the Court of Appeal has noted in this case "the absence of any justification for the expenses stated (costs of secondment of an engineer and a conductor of works, costs of study of reinforced concrete, plans, reprography). ${ }^{100}$

Furthermore, the expenses incurred by the claimant (the injured party) should not be due to his fault, such as the result of his naivety, lack of caution ${ }^{101}$ or lack of experience. For example, conducting a technical study that is not required by the negotiated project to be concluded, in such cases the injured party may not get these expenses refunded. ${ }^{102}$ In this context, the French Court of Cassation has decided that: "in the absence of a firm and definitive agreement, the harm suffered by the victim of a wrongful termination of the negotiations consists only of the costs occasioned by the negotiation and the preliminary studies. This loss, therefore, does not include the consequences of the immobilization, during the duration of the negotiations, of the property whose sale was envisaged, unless the parties to the negotiations had agreed that the seller could not conclude with third parties during this period any contract in respect of that property". ${ }^{103}$ Finally, it is stipulated that the normal expenses paid by the negotiator in order to attract his clients should not be compensated, since they are included in the general and ordinary expenses of the company and are borne by the professionals alone. ${ }^{104}$

\subsubsection{Compensation of Lost Profits}

The Palestinian legislative (as mentioned earlier) has established a general rule: "in all cases, the compensation shall be assessed on the basis of the amount of harm suffered by the victim, together with loss of profit, provided that is a natural result of the harmful act" ${ }^{105}$ This has been confirmed also in the first paragraph of article 239 of the PDCC, which declared that: "the compensation shall include the amount of harm suffered by the victim, together with loss of profit, provided that this is a natural consequence of failure to fulfil the obligation in whole or in part, or a delay in its fulfilment. However, damage is the natural consequence if the creditor cannot avoid it by making a reasonable effort". Thus, as a general rule for tortious liability in the PDCC, the debtor is obliged to compensate the loss of profits together with the damages suffered by the victim. The main question, however, lies in the extent to which this rule can be applied to the damages caused by breaching negotiations without a serious or objective justification.

The compensation of the negotiator for the lost profit (the profit that has been expected if the final contract had been concluded) is difficult to be accepted at the negotiation phase, saying otherwise, pushes us to arrange an impact for a contract which has not yet been concluded. Besides that, the judgment of compensation for this profit means applying the final contract or the negotiated agreement itself and compensation for non-fulfilment of contractual obligations arising from it, ${ }^{106}$ and this is contrary to the fact that the final contract or negotiated agreement (fixed in the negotiating documents in the pre-contract) has not yet been concluded. Another result from this is that the will of the two parties will be replaced by the will of the judge. ${ }^{107}$ Furthermore, the conclusion of the final contract at the negotiation phase is not certain. ${ }^{108}$ Therefore, compensation should not include the uncertain potential damages. ${ }^{109}$

\footnotetext{
${ }^{99}$ Abdellah, K. R. (2000). Negotiate the Contract. Supra note, p 624.

${ }^{100}$ See the French Court of Cassation, Civil Room 3, Public Sitting of Thursday 30 November 2017, No of Appeal: 14-20449. Retrieved from https://www.legifrance.gouv.fr/affichJuriJudi.do?oldAction=rechExpJuriJudi\&idTexte=JURITEXT000036138922\&fastReqId=1779101012 $\&$ fastPos $=2$ visited on 28/7/2018.

${ }^{101}$ See the French Court of Cassation, Commercial Room, Public Sitting of Wednesday 26 April 2017, No of Appeal: 15-27865. Retrieved from

https://www.legifrance.gouv.fr/affichJuriJudi.do?oldAction=rechExpJuriJudi\&idTexte=JURITEXT000034556153\&fastReqId=1009431457 \&fastPos $=2$ visited on 29/7/2018

${ }^{102}$ See Saleh, A. A. (2011). Negotiations in International Commercial Contracts. Supra note, p 769.

${ }^{103}$ See the French Court of Cassation, Commercial Room, Public Sitting of Tuesday 11 July 2006, No of Appeal: 04-16773. Retrieved from https://www.legifrance.gouv.fr/affichJuriJudi.do?oldAction=rechExpJuriJudi\&idTexte=JURITEXT000007504525\&fastReqId=1338289966 \&fastPos $=58$ visited on 29/7/2018.

${ }^{104}$ See Lutfi, H. M. (1995). Civil Responsibility in the Negotiation Phase, A Study in Egyptian and French Law. Supra note, p 92. Le Tourneau, P. (1990). Les professionnels ont-ils du coeur? p 21.

${ }^{105}$ Article 186 of the PDCC.

${ }^{106}$ See Saleh, A. A. (2011). Negotiations in International Commercial Contracts. Supra note, p 228.

${ }^{107}$ See Lutfi, H. M. (1995). Civil Responsibility in the Negotiation Phase, A Study in Egyptian and French Law. Supra note, p 90.

${ }^{108}$ See Melhem, H. S. (2010). Negotiating Contracts Through the Internet. Supra note, p 101.

${ }^{109}$ This is what the French legislature has recently addressed in the text of article 1112 of the new French Decree N 131-2016 of 10 February 2016, which state: "in case of fault committed during the negotiations, the reparation of the resulting loss is not calculated so as to compensate the loss of benefits which were expected from the contract that was not concluded".
} 
Thus, the new French Decree N 131-2016 of 10 February 2016 expressly states that compensation for loss of profits cannot be made if a fault is made in the negotiations. The French legislature thus confirms the French court's determination regarding compensation for abusive breaching during the pre-contract negotiations, which it limited to the amount of harm suffered by the victim. This is clearly demonstrated by the decision of the Third Civil Room of the French Court of Cassation, which stated that: "the circumstances constituting a fault committed in the exercise of the right of unilateral termination of the pre-contractual negotiations are not the cause of harm consisting in the loss of a chance to contract". ${ }^{110}$

\subsubsection{Compensation for Loss of a Chance to Contract}

The loss of profits as mentioned above is not compensated for in the negotiations phase since it is an unrealized damage (uncertain potential damages). However, mere deprivation of the usual development of things, which were potentially profitable in themselves, could be considered as a certain harm; namely, the loss of a chance to contract. ${ }^{111}$ The jurists have defined the loss of chance to contract as deprivation of a serious and real chance to achieve a potential profit. ${ }^{112}$

Referring to the provisions of Articles 186 and 239 of the PDCC, we find that the Palestinian legislature has created the legal basis for the plaintiff to claim compensation for loss of a chance to contract, ${ }^{113}$ contrary to what the French legislature clearly decided in article 1112 of the new French Decree N 131-2016 of 10 February 2016. This decision is based on the following justifications: firstly, the absence of a causal relationship between the abusive breaching of the negotiations and this damage (loss of chance to contract); and secondly based on the principle of contractual freedom which governs the pre-contracting phase $;^{114}$ thirdly, because compensation for the loss of a chance to contract in particular indirectly means an impact arrangement on the contract that has not been concluded and, therefore, compensation for loss of profits. ${ }^{115}$

However, the issue of compensation for losing the chance to conclude the negotiated contract raised a wide controversy involving opposition and support. In this regard, before the enactment of the new French Decree N 131-2016 of 10 February 2016, the French judiciary expressed a firm stance towards such compensation. ${ }^{116}$ Nevertheless, in a later development, the judiciary gradually accepted the matter of compensating for the loss of chance under certain terms. ${ }^{117}$ These developments are representing the tendency of several legal jurists and judiciary decisions to recognize that the loss of the chance to conclude the negotiated contract should be compensated, provided that if the circumstances show that negotiations have entered a crucial phase of being successful, and the negotiating parties were about to reach agreement on the conclusion of the final contract; thus,

\footnotetext{
110 The French Court of Cassation, Civil Room 3, Public Sitting of Thursday 30 November 2017, No of Appeal: 14-20449. Retrieved from https://www.legifrance.gouv.fr/affichJuriJudi.do?oldAction=rechExpJuriJudi\&idTexte=JURITEXT000036138922\&fastReqId=337204860\& fastPos $=3$ visited on 30/7/2018.

French Court of Cassation, Civil Room 3, Public Sitting of Thursday, 7 September 2017, No of Appeal: 15-21862. Retrieved from https://www.legifrance.gouv.fr/affichJuriJudi.do?oldAction=rechExpJuriJudi\&idTexte=JURITEXT000035538620\&fastReqId=341612853\& fastPos $=5$ visited on 30/7/2018.

French Court of Cassation, Civil Room 3, Public Sitting of Tuesday, 7 July 2015, No of Appeal: 14-20536. Retrieved from https://www.legifrance.gouv.fr/affichJuriJudi.do?oldAction=rechExpJuriJudi\&idTexte=JURITEXT000030878679\&fastReqId=1779947045 $\&$ fastPos $=9$ visited on 30/7/2018.

French Court of Cassation, Civil Room 1, Public Sitting of Thursday, 19 December 2013, No of Appeal: 12-26459. Retrieved from https://www.legifrance.gouv.fr/affichJuriJudi.do?oldAction=rechExpJuriJudi\&idTexte=JURITEXT000028357319\&fastReqId=1402958368 \&fastPos $=10$ visited on 30/7/2018.

French Court of Cassation, Civil Room 3, Public Sitting of Tuesday 28 May 2013, No of Appeal: 12-18263. Retrieved from https://www.legifrance.gouv.fr/affichJuriJudi.do?oldAction=rechExpJuriJudi\&idTexte=JURITEXT000027490668\&fastReqId=150409640\& fastPos $=11$ visited on 30/7/2018.

${ }^{111}$ See Saleh, A. A. (2011). Negotiations in International Commercial Contracts. Supra note, p 774.

${ }^{112}$ See Ashmawi, I. A. (2000). Missed Chances. Cairo, Egypt: Dar Alnahdah Alearabia. p 45.

${ }^{113}$ See the Official Explanatory of the Palestinian Civil Code Draft. Unpublished Manuscript. p 282.

114 Jamal, M. (2002). The Willingness of Contracting. Supra note, $\mathrm{p} 250$.

${ }^{115}$ Chénedé, F. (2016). Le nouveau droit des obligations et des contrats: consolidations, innovations, perspectives. Paris, France: Dalloz. P 33.

${ }^{116}$ See the decisions of the French Court of Cassation, which are mentioned in margin No 104.

117 This approach was taken by some of the judges and jurisprudence French, based on the fact that the second paragraph of article 1112 of the new French Decree N 131-2016, expressly provided only for the exclusion of loss of profit, while the loss of chance could be compensated if certain conditions were met. See Deshayes, O., Genicon, T., \& Laithier, Y. M. (2016). Réforme du droit des contrats, du régime général et de la preuve des obligations: commentaire article par article. Supra note, p 77. Chantepie, G., \& Latina, M. (2016). La réforme du droit des obligations. Commentaire théorique et pratique dans l'ordre du code civil. Paris, France: Dalloz. p 148.
} 
the breaching of the negotiations arbitrarily and without a serious or objective justification in the presence of a genuine and confirmed chance to conclude the final contract is deserving of a compensation. ${ }^{118}$

In this trend, the French Court of Cassation ruled that: "the loss of chance is compensable only if the victim proves the reality of the favourable prospect that she alleges has lost a chance of obtaining it". ${ }^{119}$ However, this decision emphasizes the need to distinguish between loss of profits, which has become impossible, that cannot be compensated for the reasons mentioned earlier, and the loss of chance to achieve profits, ${ }^{120}$ which is a sure instance of damage requiring compensation ${ }^{121}$ which must be proven by the plaintiff. ${ }^{122}$

The above is related to the loss of the chance to contract with the other negotiator, and here the question arises about the possibility of compensation for losing the chance to conclude an alternative contract with another party. Besides that, is it permissible to compensate for the loss of the chance of non-performance of contracts concluded by the injured negotiator with others, in order to prepare for the implementation of the contract to be concluded, which is being negotiated?

With regards to the first part of the question, some of the legal jurists, supported by judiciary decisions, ${ }^{123}$ argued that the injured negotiator has the right to claim compensation for losing the chance to conclude another contract rather than the negotiated contract provided that he had abandon the chance to conclude the other contract in good faith, and relying on the pseudo prospect created by the other negotiator, which made him believe the contract under negotiation would inevitably be concluded. ${ }^{124}$ In other words, a negotiator who interrupts or breaches negotiations without relying on a serious or objective justification is liable to claim compensation for losing the chance to conclude an alternative contract with others if this chance is serious, real and existing and the reason for the loss of this chance is not due to the naivete of the injured negotiator, his fault,

\footnotetext{
118 This trend is supported by the provisions of the second paragraph of article (7.4.3) UNIDROIT principles of 2016 states: "compensation may be due for the loss of a chance in proportion to the probability of its occurrence". See also French Court of Cassation, Civil Room 2, Public Sitting of Thursday, 2 March 2017, No of Appeal: 16-11548. Retrieved from

https://www.legifrance.gouv.fr/affichJuriJudi.do?oldAction=rechExpJuriJudi\&idTexte=JURITEXT000034144612\& fastReqId=742195130\& fastPos $=80$ visited on $2 / 8 / 2018$

French Court of Cassation, Civil Room 2, Public Sitting of Thursday, 2 March 2017, No of Appeal: 16-11550. Retrieved from https://www.legifrance.gouv.fr/affichJuriJudi.do?oldAction=rechExpJuriJudi\&idTexte=JURITEXT000034144626\&fastReqId=742195130\& fastPos $=79$ visited on $2 / 8 / 2018$

French Court of Cassation, Civil Room 2, Public Sitting of Thursday, 2 March 2017, No of Appeal: 16-11555. Retrieved from https://www.legifrance.gouv.fr/affichJuriJudi.do?oldAction=rechExpJuriJudi\&idTexte=JURITEXT000034144803\&fastReqId=742195130\& fastPos $=77$ visited on $2 / 8 / 2018$

French Court of Cassation, Civil Room 3, Public Sitting of Thursday 24 November 2016, No of Appeal: 15-19073. Retrieved from https://www.legifrance.gouv.fr/affichJuriJudi.do?oldAction=rechExpJuriJudi\&idTexte=JURITEXT000033485873\&fastReqId=1813100363 $\&$ fastPos $=101$ visited on $2 / 8 / 2018$.

${ }^{119}$ See the French Court of Cassation, Civil Room 2, Public Sitting of Thursday, 2 March 2017, No of Appeal: 16-11559. Retrieved from https://www.legifrance.gouv.fr/affichJuriJudi.do?oldAction=rechExpJuriJudi\&idTexte=JURITEXT000034144909\& fastReqId=1034322641 $\&$ fastPos $=20$ visited on $3 / 8 / 2018$.

${ }^{120}$ See the French Court of Cassation, Civil Room 3, Public Sitting of Thursday, May 17, 2018, No of Appeal: 17-11760. Retrieved from https://www.legifrance.gouv.fr/affichJuriJudi.do?oldAction=rechExpJuriJudi\&idTexte=JURITEXT000036947234\&fastReqId=1323447984 \&fastPos $=7$ visited on $3 / 8 / 2018$.

${ }^{121}$ See Salama, A. A. (2001). International Contract Law, International Contract Negotiations, Law of will and its Crisis. Cairo, Egypt: Dar Alnahdah Alearabiah. P 122.

${ }^{122}$ The French Court of Cassation ruled: "the circumstances constituting a fault in the exercise of the right of unilateral termination of the pre-contractual negotiation are not the cause of the harm consisting in the loss of a chance to realize the profits". French Court of Cassation, Commercial Room, Public Sitting of Tuesday 18 September 2012, No of Appeal: 11-19629. Retrieved from

https://www.legifrance.gouv.fr/affichJuriJudi.do?oldAction=rechExpJuriJudi\&idTexte=JURITEXT000026397554\&fastReqId=991405102\& fastPos $=19$ visited on 3/8/2018.

${ }^{123}$ See Saleh, A. A. (2011). Negotiations in International Commercial Contracts. Supra note, p 789.

${ }^{124}$ See the French Court of Cassation, Commercial Room, Public Sitting of Wednesday 18 January 2017, No of Appeal: 15-13392 15-14661. Retrieved from

https://www.legifrance.gouv.fr/affichJuriJudi.do?oldAction=rechExpJuriJudi\&idTexte=JURITEXT000033903545\&fastReqId=950513147\& fastPos $=94$ visited on $5 / 8 / 2018$

French Court of Cassation, Civil Room 3, Public Sitting of Thursday 24 November 2016, No of Appeal: 15-24909. Retrieved from https://www.legifrance.gouv.fr/affichJuriJudi.do?oldAction=rechExpJuriJudi\&idTexte=JURITEXT000033486371\& fastReqId=950513147\& fastPos=101 visited on 5/8/2018.
} 
or his lack of caution ${ }^{125}$ or lack of experience. ${ }^{126}$

It should be noted that the compensation for losing the chance to conclude an alternative contract raises some quandaries. Particularly, the way to prove that the injured negotiator would have definitively concluded an alternative contract to the contract for which negotiations were being conducted, if he had not entered into negotiations with the other party who breached the negotiations without any objective justification. ${ }^{127}$ It also requires that the amount of compensation for losing the chance to conclude an alternative contract with third parties should not exceed the amount of the expected profits from the contract which is intended to be concluded, if it were concluded actually. ${ }^{128}$

However, with regard to the second part of the question, it is customary in the field of commercial and civil transactions that the client who wishes to contract, at the time of the negotiations, conclude many contracts that have been necessary to prepare for the implementation of the negotiated contract, such as concluding an insurance contract on the elements of the negotiated project with an insurance company. Therefore, breaching off negotiations without a serious or objective justification will inevitably lead to the non-implementation of such auxiliary or supplementary contracts to the negotiated contract. ${ }^{129}$

Based on the above assumption, is it permissible for the injured negotiator to seek compensation for damages of which he is deserving in favour of third parties (insurance company), due to his failure to execute the contracts concluded with them as a result of breaching the negotiations?

Here we must differentiate between two situations: the first is that the negotiator who terminated the negotiations without a serious or objective justification knew of these contracts, which the injured negotiator has made and did not object to them, but urged the injured negotiator to conclude them. Justice and logic dictate that this negotiator (responsible for termination of negotiations) shall be liable to pay the damages owed upon the injured negotiator for the third party, ${ }^{130}$ where the negotiator who breaches the negotiations is the one who made the injured negotiator firmly believe that the contract is going to be concluded surely.

The second situation is that if the negotiator (responsible for termination of negotiations) does not know about the existence of such supplementary contracts or is aware of them and objects to them, in such case the injured negotiator cannot claim the damages owed upon the injured negotiator to the third party based on the following justifications: ${ }^{131}$ firstly, concluding supplementary contracts with third parties without the knowledge of the other negotiator is not expected at the negotiations phase. Secondly, a negotiator who is keen on his own interests does not agree to conclude supplementary contracts with third parties until after the negotiated contract is concluded, during this time the negotiated contract remains in the circle of probability and it is not possible to determine whether it is going to be concluded or not.

From the point of view of the researcher, the negotiator who makes supplementary contracts to the negotiated contract with the aim of proving his seriousness and keenness to conclude the negotiated contract may take the necessary precautions to prevent him from assuming the liability that arises from the non-implementation of such auxiliary or supplementary contracts, by including in it a condition that makes its conclusion contingent on the

\footnotetext{
${ }^{125}$ See the French Court of Cassation, Commercial Room, Public Sitting of Wednesday 26 April 2017, No of Appeal: 15-27865. Retrieved from

https://www.legifrance.gouv.fr/affichJuriJudi.do?oldAction=rechExpJuriJudi\&idTexte=JURITEXT000034556153\&fastReqId=1009431457 $\&$ fastPos $=2$ visited on 5/8/2018.

${ }^{126}$ See Al-arabii, B. (2011). Problems of the Pre-contracting Phase in Light of Algerian Civil Code. Supra note, $\mathrm{p} 423$.

${ }^{127}$ See the French Court of Cassation, Civil Room 1, Public Sitting of Wednesday 12 October 2016, No of Appeal: 15-20320. Retrieved from https://www.legifrance.gouv.fr/affichJuriJudi.do?oldAction=rechExpJuriJudi\&idTexte=JURITEXT000033268840\&fastReqId=950513147\& fastPos=108 visited on 5/8/2018.

French Court of Cassation, Civil Room 1, Public Sitting of Thursday, 18 December 2014, No of Appeal: 13-23178. Retrieved from https://www.legifrance.gouv.fr/affichJuriJudi.do?oldAction=rechExpJuriJudi\&idTexte=JURITEXT000029936776\&fastReqId=1069875204 \&fastPos $=180$ visited on 5/8/2018.

${ }^{128}$ The French Court of Cassation ruled that: "the loss of chance cannot be equal to the advantage that this chance would have provided if it has been realized. ..". See French Court of Cassation, Commercial Room, Public Sitting of Tuesday 22 November 2016, No of Appeal: 15-16613. Retrieved from

https://www.legifrance.gouv.fr/affichJuriJudi.do?oldAction=rechExpJuriJudi\&idTexte=JURITEXT000033486633\&fastReqId=950513147\& fastPos=104 visited on 5/8/2018.

${ }^{129}$ See Saleh, A. A. (2011). Negotiations in International Commercial Contracts. Supra note, p 792.

${ }^{130}$ See Lutfi, H. M. (1995). Civil Responsibility in the Negotiation Phase, A Study in Egyptian and French Law. Supra note, p 96-97.

${ }^{131}$ See Saleh, A. A. (2011). Negotiations in International Commercial Contracts. Supra note, p 794.
} 
condition of the conclusion of the negotiated contract, or otherwise inform the other negotiator of his intention to conclude supplementary contracts.

\section{The Legislative Deficiencies in the Legislative Remedies of the Subject of Good Faith in Preliminary Negotiations at the Pre-Contracting Phase in the Provisions of Tort Liability of the PDCC}

Based on what we have explained above (in the tort liability terms and consequential compensation), we find out that there are a number of legislative flaws due to the absence of a legislative article that obliges the negotiating parties to negotiate in good faith at the negotiation phase, the most important of which are the following:

First, the legal basis for requiring the injured party to compensate for the abusive breaching of pre-contracting negotiations or the breaching of negotiations without any objective justification is not because the other negotiator has violated the principle of good faith, but on the basis of his tort liability for the damage caused by his action, since there is no legal provision in the PDCC requiring him to negotiate good faith. ${ }^{132}$

Second, the argument that there is no need to legislate a legal provision which obliges the parties to negotiate in good faith, based on the fact that the French Civil Code of 1804 did not contain a similar provision. Nevertheless, the French judiciary applied the principle of good faith as one of the most substantial principles governing the negotiation phase. Therefore, it can be inferred that the Palestinian judiciary's ability to follow in the same track, as a claim, is illogical.

Third, replacing a provision that requires good faith in negotiations with the provisions of tort liability causes many of the problems that have already been discussed above, such as: that the exercise of the rules of tort liability requires the judge to rule starting the implementation in-kind whenever possible, which is contrary to the legal principles governing the negotiations phase and violates the personal freedom of the individual. ${ }^{133}$ Furthermore, the tort liability in the Palestinian Civil Code Draft does not include compensation for non-action (refrain from doing an act) which can entail damages. ${ }^{134}$ Besides that, the application of the provisions of tort liability to abusive breaching of negotiations will result in compensating the injured negotiator for the loss of profits, which is difficult to be accepted at the negotiation phase. ${ }^{135}$

\section{Conclusion}

The negotiation phase has not been given any legal regulation obliging its parties to negotiate in good faith in the Palestinian Civil Code Draft ignoring the importance and function of this principle in the negotiations phase, in compliance with the Arab legislations of civil law, especially the Egyptian Civil Code, the provisions of which are derived from the French legislation of 1804. Although adherence to the principle of good faith is enshrined in the Palestinian Civil Code Draft, the Palestinian legislature has limited its application to the phase of the implementation of the contract.

However, the jurisprudential and judicial legal trend now tends to apply the principle of good faith at the negotiation phase as one of the most important principles governing this stage, since it is inconceivable that the parties are to negotiate in bad faith (mala fide), and then must implement the contract in good faith, in accordance with the traditional legal rule that "fraud spoils everything it touches".

In view of this, and in conjunction with the function of the principle of good faith in the negotiations phase, the Palestinian legislature must intervene urgently by legislating a legal article which obligates the negotiating parties to behave in good faith, as this has become an unavoidable reality that should be dealt with to contribute to the stability of civil and commercial transactions. However, the legal article should also specify the compensation to be claimed.

\section{References}

Abdel Aal, H. M. (1998). The Conventional Organization of Contractual Negotiations. Cairo, Egypt: Dar Alnahdah Alearabiah.

Abdellah, K. R. (2000). Negotiate the Contract. Cairo, Egypt: Dar Alnahdah Alearabia.

Abell, M., \& Hobbs, V. (2014). Duty of good faith in franchise agreements a comparative study of the civil and common law approaches in the eu. International Journal of Franchising Law, 12(1), 25-40.

Al Mulla, A. (2017). The Principle of Good Faith in Contracts: Qatari Law Perspective. Asian Business Lawyer

\footnotetext{
${ }^{132}$ See page No: 8 .

133 See page No: 13-14.

${ }^{134}$ See page No: 12.

${ }^{135}$ See page No: 17-18.
} 
$19,115-134$.

Al-arabii, B. (2011). Problems of the Pre-contracting Phase in Light of Algerian Civil Code. Algeria, Algeria: Diwan Almatbueat Aljamieia.

Aryan, S., \& Mirabbasi, B. (2016). The Good Faith Principle and its Consequences in Pre-contractual Period: Comparative Study on English and French Law. Journal of Politics and Law, 9(2), 232-245.

Ashmawi, I. A. (2000). Missed Chances. Cairo, Egypt: Dar Alnahdah Alearabia.

Beautridge, J. (2016). Understanding Good Faith in the Context of Contractual Performance: Lessons to Learn from the German System. Anglo-German Law Journal, 2, 39-63.

Bonis, P. (2016). Bona fides Exuberans: New Legal Concept of Twelfth Century Legal Scholarship. Journal on European History of Law, 7(2), 97-101.

Chantepie, G., \& Latina, M. (2016). La réforme du droit des obligations. Commentaire théorique et pratique dans l'ordre du code civil. Paris, France: Dalloz.

Chénedé, F. (2016). Le nouveau droit des obligations et des contrats: consolidations, innovations, perspectives. Paris, France: Dalloz.

Cremades, B. M. (2012). Good Faith in International Arbitration. American University International Law Review, 27(4), 761-788.

Deshayes, O., Genicon, T., \& Laithier, Y. M. (2016). Réforme du droit des contrats, du régime général et de la preuve des obligations: commentaire article par article. LexisNexis.

Doris, M. (2014). Promising Options, Dead Ends and the Reform of Australian Contract Law. Legal Studies, 34(1), 24-46.

Estrella Faria, J. A. (2016). The Influence of the UNIDROIT Principles of International Commercial Contracts on National Laws. Uniform Law Review, 21(2-3), 238-270.

Fadily, I. (2009). Brief in the General Theory of Commitment. Algeria, Algeria: Diwan Almatbueat Aljamieiat.

Fayyad, M. (2014). Measures of the principle of good faith in european consumer protection and islamic law, comparative analysis. Arab Law Quarterly, 28(3), 205-230.

Febbrajo, T. (2016). Good Faith and Pre-contractual Liability in Italy: Recent Developments in the Interpretation of article 1337 of the Italian Civil Code. Italian Law Journal, 2(2), 291-312.

Feinman, J. M. (2014). Good Faith and Reasonable Expectations. Arkansas Law Review, 67(3), 525-570.

Foldi, A. (2007). Remarks on the Notion of Bona Fides. Annales Universitatis Scientiarum Budapestinensis de Rolando Eotvos Nominatae: Sectio Iuridica, 48, 53-72.

French Court of Cassation, Civil Room 1, Public Sitting of Tuesday, 9 July 1991, No of Appeal: 89-19931. Retrieved

from https://www.legifrance.gouv.fr/affichJuriJudi.do?oldAction=rechExpJuriJudi\&idTexte=JURITEXT0000071 34780\&fastReqId=1107460832\&fastPos=46 visited on 27/7/2018.

French Court of Cassation, Civil Room 1, Public Sitting of Thursday, 19 December 2013, No of Appeal: 12-26459. Retrieved

from https:/www.legifrance.gouv.fr/affichJuriJudi.do?oldAction=rechExpJuriJudi\&idTexte=JURITEXT0000283 57319\&fastReqId=1402958368\&fastPos=10 visited on 30/7/2018.

French Court of Cassation, Civil Room 1, Public Sitting of Thursday, 18 December 2014, No of Appeal: 13-23178.

Retrieved

from https://www.legifrance.gouv.fr/affichJuriJudi.do?oldAction=rechExpJuriJudi\&idTexte=JURITEXT0000299 $36776 \&$ fastReqId=1069875204\&fastPos $=180$ visited on $5 / 8 / 2018$.

French Court of Cassation, Civil Room 1, Public Sitting of Wednesday, January 26, 2011, No of Appeal: $10-10115$.

Retrieved

from https://www.legifrance.gouv.fr/affichJuriJudi.do?oldAction=rechExpJuriJudi\&idTexte=JURITEXT0000234 96233\&fastReqId=1786260969\&fastPos $=1$ visited on 21/7/2018.

French Court of Cassation, Civil Room 1, Public Sitting of Wednesday, 14 December 2016, No of Appeal: $15-25352$.

Retrieved

from

https://www.legifrance.gouv.fr/affichJuriJudi.do?oldAction=rechExpJuriJudi\&idTexte=JURITEXT0000336 
$31635 \&$ fastReqId $=1809616963 \&$ fastPos $=2$ visited on $21 / 7 / 2018$.

French Court of Cassation, Civil Room 1, Public Sitting of Wednesday, 1 June 2016, No of Appeal: 15-13221. Retrieved https://www.legifrance.gouv.fr/affichJuriJudi.do?oldAction=rechExpJuriJudi\&idTexte=JURITEXT0000326 $35842 \&$ fastReqId $=883482089 \&$ fastPos $=3$ visited on 21/7/2018.

French Court of Cassation, Civil Room 1, Public Sitting of Wednesday, 1 June 2011, No of Appeal: 10-30205. Retrieved https://www.legifrance.gouv.fr/affichJuriJudi.do?oldAction=rechExpJuriJudi\&idTexte=JURITEXT0000241 $17411 \&$ fastReqId $=551790077 \&$ fastPos $=15$ visited on 21/7/2018.

French Court of Cassation, Civil Room 1, Public Sitting of Wednesday 30 November 2016, No of Appeal: 14-18818. Retrieved

from https://www.legifrance.gouv.fr/affichJuriJudi.do?oldAction=rechExpJuriJudi\&idTexte=JURITEXT0000335 $27603 \&$ fastReqId $=969675883 \&$ fastPos $=81$ visited on 22/7/2018.

French Court of Cassation, Civil Room 1, Public Sitting of Wednesday, 19 January 1977, No of Appeal: 75-14096. Retrieved https://www.legifrance.gouv.fr/affichJuriJudi.do?oldAction=rechExpJuriJudi\&idTexte=JURITEXT0000069 98645\& fastReqId $=1530491333 \&$ fastPos $=7$ visited on 27/7/2018.

French Court of Cassation, Civil Room 1, Public Sitting of Wednesday 12 October 2016, No of Appeal: 15-20320. Retrieved from https://www.legifrance.gouv.fr/affichJuriJudi.do?oldAction=rechExpJuriJudi\&idTexte=JURITEXT0000332 68840\& fastReqId=950513147\& fastPos $=108$ visited on 5/8/2018.

French Court of Cassation, Civil Room 2, Public Sitting of Thursday, 2 March 2017, No of Appeal: 16-11548. Retrieved https://www.legifrance.gouv.fr/affichJuriJudi.do?oldAction=rechExpJuriJudi\&idTexte=JURITEXT0000341 $44612 \&$ fastReqId $=742195130 \&$ fastPos $=80$ visited on $2 / 8 / 2018$.

French Court of Cassation, Civil Room 2, Public Sitting of Thursday, 2 March 2017, No of Appeal: 16-11550. Retrieved https://www.legifrance.gouv.fr/affichJuriJudi.do?oldAction=rechExpJuriJudi\&idTexte=JURITEXT0000341 $44626 \&$ fastReqId $=742195130 \&$ fastPos $=79$ visited on $2 / 8 / 2018$.

French Court of Cassation, Civil Room 2, Public Sitting of Thursday, 2 March 2017, No of Appeal: 16-11555. Retrieved https://www.legifrance.gouv.fr/affichJuriJudi.do?oldAction=rechExpJuriJudi\&idTexte=JURITEXT0000341 $44803 \&$ fastReqId $=742195130 \&$ fastPos $=77$ visited on $2 / 8 / 2018$.

French Court of Cassation, Civil Room 2, Public Sitting of Thursday, 2 March 2017, No of Appeal: 16-11559. Retrieved https://www.legifrance.gouv.fr/affichJuriJudi.do?oldAction=rechExpJuriJudi\&idTexte=JURITEXT0000341 44909\& fastReqId $=1034322641 \&$ fastPos $=20$ visited on 3/8/2018.

French Court of Cassation, Civil Room 3, Public Sitting of Thursday 30 November 2017, No of Appeal: 14-20449.

Retrieved

from https://www.legifrance.gouv.fr/affichJuriJudi.do?oldAction=rechExpJuriJudi\&idTexte=JURITEXT0000361 $38922 \&$ fastReqId $=1680998632 \&$ fastPos $=1$ visited on 21/7/2018.

French Court of Cassation, Civil Room 3, Public Sitting of Thursday 22 June 2017, No of Appeal: 16-17946. Retrieved https://www.legifrance.gouv.fr/affichJuriJudi.do?oldAction=rechExpJuriJudi\&idTexte=JURITEXT0000350 $05152 \&$ fastReqId $=969675883 \&$ fastPos $=50$ visited on 22/7/2018.

French Court of Cassation, Civil Room 3, Public Sitting of Thursday, 16 November 2017, No of Appeal: $15-12268$. Retrieved https://www.legifrance.gouv.fr/affichJuriJudi.do?oldAction=rechExpJuriJudi\&idTexte=JURITEXT0000360 $56240 \&$ fastReqId $=1383574738 \&$ fastPos $=33$ visited on 22/7/2018.

French Court of Cassation, Civil Room 3, Public Sitting of Thursday 15 June 2017, No of Appeal: 16-15916. Retrieved https://www.legifrance.gouv.fr/affichJuriJudi.do?oldAction=rechExpJuriJudi\&idTexte=JURITEXT0000349 
$62442 \&$ fastReqId $=318284979 \&$ fastPos $=71$ visited on 22/7/2018.

French Court of Cassation, Civil Room 3, Public Sitting of Thursday 23 November 2017, No of Appeal: 16-21127. Retrieved from https://www.legifrance.gouv.fr/affichJuriJudi.do?oldAction=rechExpJuriJudi\&idTexte=JURITEXT0000360 95021\&fastReqId $=538796450 \&$ fastPos $=3$ visited on 23/7/2018.

French Court of Cassation, Civil Room 3, Public Sitting of Thursday, February 18, 2016, No of Appeal: 15-12706.

Retrieved

from https://www.legifrance.gouv.fr/affichJuriJudi.do?oldAction=rechExpJuriJudi\&idTexte=JURITEXT0000320 $86870 \&$ fastReqId $=576682998 \&$ fastPos $=18$ visited on $28 / 7 / 2018$.

French Court of Cassation, Civil Room 3, Public Sitting of Thursday, February 18, 2016, No of Appeal: 15-12714. Retrieved from https://www.legifrance.gouv.fr/affichJuriJudi.do?oldAction=rechExpJuriJudi\&idTexte=JURITEXT0000320 87203\&fastReqId $=804351739 \&$ fastPos $=21$ visited on 28/7/2018.

French Court of Cassation, Civil Room 3, Public Sitting of Thursday 30 November 2017, No of Appeal: 14-20449. Retrieved https://www.legifrance.gouv.fr/affichJuriJudi.do?oldAction=rechExpJuriJudi\&idTexte=JURITEXT0000361 $38922 \&$ fastReqId $=1779101012 \&$ fastPos $=2$ visited on 28/7/2018.

French Court of Cassation, Civil Room 3, Public Sitting of Thursday 30 November 2017, No of Appeal: 14-20449.

Retrieved

from https://www.legifrance.gouv.fr/affichJuriJudi.do?oldAction=rechExpJuriJudi\&idTexte=JURITEXT0000361 $38922 \&$ fastReqId $=337204860 \&$ fastPos $=3$ visited on 30/7/2018.

French Court of Cassation, Civil Room 3, Public Sitting of Thursday, 7 September 2017, No of Appeal: $15-21862$.

Retrieved

from https://www.legifrance.gouv.fr/affichJuriJudi.do?oldAction=rechExpJuriJudi\&idTexte=JURITEXT0000355 38620\& fastReqId $=341612853 \&$ fastPos $=5$ visited on 30/7/2018.

French Court of Cassation, Civil Room 3, Public Sitting of Thursday 24 November 2016, No of Appeal: 15-19073. Retrieved from https://www.legifrance.gouv.fr/affichJuriJudi.do?oldAction=rechExpJuriJudi\&idTexte=JURITEXT0000334 85873\&fastReqId $=1813100363 \&$ fastPos $=101$ visited on $2 / 8 / 2018$.

French Court of Cassation, Civil Room 3, Public Sitting of Thursday 24 November 2016, No of Appeal: 15-24909. https://www.legifrance.gouv.fr/affichJuriJudi.do?oldAction=rechExpJuriJudi\&idTexte=JURITEXT0000334 $86371 \&$ fastReqId $=950513147 \&$ fastPos $=101$ visited on 5/8/2018.

French Court of Cassation, Civil Room 3, Public Sitting of Thursday, May 17, 2018, No of Appeal: 17-11760. Retrieved https://www.legifrance.gouv.fr/affichJuriJudi.do?oldAction=rechExpJuriJudi\&idTexte=JURITEXT0000369 $47234 \&$ fastReqId $=1323447984 \&$ fastPos $=7$ visited on $3 / 8 / 2018$.

French Court of Cassation, Civil Room 3, Public Sitting of Tuesday 8 December 2009, No of Appeal: 08-18920. Retrieved https://www.legifrance.gouv.fr/affichJuriJudi.do?oldAction=rechExpJuriJudi\&idTexte=JURITEXT0000214 $75246 \&$ fastReqId $=804351739 \&$ fastPos $=41$ visited on 28/7/2018.

French Court of Cassation, Civil Room 3, Public Sitting of Tuesday, 7 July 2015, No of Appeal: 14-20536. Retrieved https://www.legifrance.gouv.fr/affichJuriJudi.do?oldAction=rechExpJuriJudi\&idTexte=JURITEXT0000308 $78679 \&$ fastReqId $=153431856 \&$ fastPos $=20$ visited on 28/7/2018.

French Court of Cassation, Civil Room 3, Public Sitting of Tuesday, 7 July 2015, No of Appeal: 14-20536. Retrieved https://www.legifrance.gouv.fr/affichJuriJudi.do?oldAction=rechExpJuriJudi\&idTexte=JURITEXT0000308 78679\& fastReqId $=1779947045 \&$ fastPos $=9$ visited on 30/7/2018.

French Court of Cassation, Civil Room 3, Public Sitting of Tuesday 28 May 2013, No of Appeal: 12-18263. Retrieved https://www.legifrance.gouv.fr/affichJuriJudi.do?oldAction=rechExpJuriJudi\&idTexte=JURITEXT0000274 
90668\& fastReqId $=150409640 \&$ fastPos $=11$ visited on 30/7/2018.

French Court of Cassation, Civil Room 3, Public Sitting of Wednesday, 14 June 2000, No of Appeal: 98-22131. Retrieved https://www.legifrance.gouv.fr/affichJuriJudi.do?oldAction=rechExpJuriJudi\&idTexte=JURITEXT0000076 17232\&fastReqId $=1456704144 \&$ fastPos $=270$ visited on 23/7/2018.

French Court of Cassation, Civil Room, Public Sitting of Thursday 30 November 2017, No of Appeal: 14-20449. Retrieved https://www.legifrance.gouv.fr/affichJuriJudi.do?oldAction=rechExpJuriJudi\&idTexte=JURITEXT0000361 $38922 \&$ fastReqId $=1383574738 \&$ fastPos $=31$ visited on $22 / 7 / 2108$.

French Court of Cassation, Commercial Room, Public Sitting of Monday, 20 March 1972, No of Appeal: 70-14154. https://www.legifrance.gouv.fr/affichJuriJudi.do?oldAction=rechExpJuriJudi\&idTexte=JURITEXT0000069 $86985 \&$ fastReqId $=962939768 \&$ fastPos $=4$ visited on $28 / 7 / 2018$.

French Court of Cassation, Commercial Room, Public Sitting of Tuesday, 9 February 2016, No of Appeal: 14-15134. https://www.legifrance.gouv.fr/affichJuriJudi.do?oldAction=rechExpJuriJudi\&idTexte=JURITEXT0000320 $57619 \&$ fastReqId $=649482122 \&$ fastPos $=12$ visited on 20/7/2018.

French Court of Cassation, Commercial Room, Public Sitting of Tuesday, 5 December 2006, No of Appeal: 05-12926.

Retrieved

from https://www.legifrance.gouv.fr/affichJuriJudi.do?oldAction=rechExpJuriJudi\&idTexte=JURITEXT0000075 13872\&fastReqId $=1787661435 \&$ fastPos $=1$ visited on 21/7/2018.

French Court of Cassation, Commercial Room, Public Sitting of Tuesday, 18 October 2016, No of Appeal: 14-27212.

Retrieved

from https://www.legifrance.gouv.fr/affichJuriJudi.do?oldAction=rechExpJuriJudi\&idTexte=JURITEXT0000332 97550\& fastReqId $=1780363868 \&$ fastPos $=1$ visited on 12/7/2018.

French Court of Cassation, Commercial Room, Public Sitting of Tuesday, 13 November 2001, No of Appeal: 99-12046. https://www.legifrance.gouv.fr/affichJuriJudi.do?oldAction=rechExpJuriJudi\&idTexte=JURITEXT0000074 $32137 \&$ fastReqId $=307382651 \&$ fastPos $=1$ visited on 21/7/2018.

French Court of Cassation, Commercial room, Public Sitting of Tuesday 17 March 2009, No of Appeal: 08-12830. https://www.legifrance.gouv.fr/affichJuriJudi.do?oldAction=rechExpJuriJudi\&idTexte=JURITEXT0000204 $22993 \&$ fastReqId $=1485572155 \&$ fastPos $=1$ visited on 21/7/2018.

French Court of Cassation, Commercial Room, Public Sitting of Tuesday 15 December 2015, No of Appeal: 14-11500. https://www.legifrance.gouv.fr/affichJuriJudi.do?oldAction=rechExpJuriJudi\&idTexte=JURITEXT0000316 $52185 \&$ fastReqId $=1291960490 \&$ fastPos $=3$ visited on 22/7/2018.

French Court of Cassation, Commercial room, Public Sitting of Tuesday, 9 February 2016, No of Appeal: 14-15134.

Retrieved from https://www.legifrance.gouv.fr/affichJuriJudi.do?oldAction=rechExpJuriJudi\&idTexte=JURITEXT0000320 $57619 \&$ fastReqId $=649482122 \&$ fastPos $=12$ visited on 23/7/2018.

French Court of Cassation, Commercial Room, Public Sitting of Tuesday, 7 March 2006, No of Appeal: 04-17177. Retrieved from https://www.legifrance.gouv.fr/affichJuriJudi.do?oldAction=rechExpJuriJudi\&idTexte=JURITEXT0000074 96851\&fastReqId $=1326058169 \&$ fastPos $=121$ visited on 23/7/2018.

French Court of Cassation, Commercial Room, Public Sitting of Tuesday, 12 January 1999, No of appeal: 96-14604. https://www.legifrance.gouv.fr/affichJuriJudi.do?oldAction=rechExpJuriJudi\&idTexte=JURITEXT0000073 $99722 \&$ fastReqId $=1288383485 \&$ fastPos $=10$ visited on 23/7/2018.

French Court of Cassation, Commercial Room, Public Sitting of Tuesday 20 November 2007, No of Appeal: 06-20332. 
$27661 \&$ fastReqId $=157743782 \&$ fastPos $=2$ visited on $23 / 7 / 2018$.

French Court of Cassation, Commercial Room, Public Sitting of Tuesday, 18 January 2011, No of Appeal: 09-14617.

Retrieved from https://www.legifrance.gouv.fr/affichJuriJudi.do?oldAction=rechExpJuriJudi\&idTexte=JURITEXT0000234 64963\& fastReqId $=1338289966 \&$ fastPos $=41$ visited on 28/7/2018.

French Court of Cassation, Commercial Room, Public Sitting of Tuesday 20 November 2007, No of Appeal: 06-17289.

Retrieved

from https://www.legifrance.gouv.fr/affichJuriJudi.do?oldAction=rechExpJuriJudi\&idTexte=JURITEXT0000076 $26821 \&$ fastReqId $=1338289966 \&$ fastPos $=57$ visited on 28/7/2018.

French Court of Cassation, Commercial Room, Public Sitting of Tuesday 11 July 2006, No of Appeal: 04-16773. Retrieved from https://www.legifrance.gouv.fr/affichJuriJudi.do?oldAction=rechExpJuriJudi\&idTexte=JURITEXT0000075 04525\&fastReqId $=1338289966 \&$ fastPos $=58$ visited on 29/7/2018.

French Court of Cassation, Commercial Room, Public Sitting of Tuesday 22 November 2016, No of Appeal: 15-16613. https://www.legifrance.gouv.fr/affichJuriJudi.do?oldAction=rechExpJuriJudi\&idTexte=JURITEXT0000334 86633\&fastReqId $=950513147 \&$ fastPos $=104$ visited on 5/8/2018.

French Court of Cassation, Commercial Room, Public Sitting of Tuesday 18 September 2012, No of Appeal: 11-19629.

Retrieved

from https://www.legifrance.gouv.fr/affichJuriJudi.do?oldAction=rechExpJuriJudi\&idTexte=JURITEXT0000263 97554\& fastReqId $=991405102 \&$ fastPos $=19$ visited on 3/8/2018.

French Court of Cassation, Commercial Room, Public Sitting of Wednesday, June 27, 2018, No of Appeal: 16-26.360.

Retrieved from https://www.legifrance.gouv.fr/affichJuriJudi.do?oldAction=rechExpJuriJudi\&idTexte=JURITEXT0000371 $96607 \&$ fastReqId $=731895665 \&$ fastPos $=1$ visited on $21 / 7 / 2018$.

French Court of Cassation, Commercial Room, Public Sitting of Wednesday 26 November 2003, No of Appeal: $00-10243$ 00-10949.

Retrieved

from https://www.legifrance.gouv.fr/affichJuriJudi.do?oldAction=rechExpJuriJudi\&idTexte=JURITEXT0000070 49778\&fastReqId $=1984111551 \&$ fastPos $=3$ visited on 21/7/2018.

French Court of Cassation, Commercial Room, Public Sitting of Wednesday, 13 June 2018, No of Appeal: 17-12038. https://www.legifrance.gouv.fr/affichJuriJudi.do?oldAction=rechExpJuriJudi\&idTexte=JURITEXT0000371 $35742 \&$ fastReqId $=903583666 \&$ fastPos $=1$ visited on $21 / 7 / 2018$.

French Court of Cassation, Commercial Room, Public Sitting of Wednesday, 13 September 2017, No of Appeal: 15-12178.

Retrieved

from https://www.legifrance.gouv.fr/affichJuriJudi.do?oldAction=rechExpJuriJudi\&idTexte=JURITEXT0000355 73369\& fastReqId $=1971868830$ \& fastPos $=40$ visited on 22/7/2018.

French Court of Cassation, Commercial room, Public Sitting of Wednesday 26 November 2003, No of Appeal: 00-10243 00-10949.

Retrieved

from https://www.legifrance.gouv.fr/affichJuriJudi.do?oldAction=rechExpJuriJudi\&idTexte=JURITEXT0000070 $49778 \&$ fastReqId $=313401159 \&$ fastPos $=1$ visited on $23 / 7 / 2018$.

French Court of Cassation, Commercial Room, Public Sitting of Wednesday 26 November 2003, No of Appeal: $00-10243$ 00-10949.

Retrieved

from https://www.legifrance.gouv.fr/affichJuriJudi.do?oldAction=rechExpJuriJudi\&idTexte=JURITEXT0000070 49778\&fastReqId $=1984111551 \&$ fastPos $=3$ visited on 28/7/2018.

French Court of Cassation, Commercial Room, Public Sitting of Wednesday, 27 September 2017, No of Appeal: 15-15820. https://www.legifrance.gouv.fr/affichJuriJudi.do?oldAction=rechExpJuriJudi\&idTexte=JURITEXT0000356 82907\& fastReqId $=1943252746 \&$ fastPos $=4$ visited on 28/7/2018.

French Court of Cassation, Commercial Room, Public Sitting of Wednesday 26 April 2017, No of Appeal: $15-27865$. https://www.legifrance.gouv.fr/affichJuriJudi.do?oldAction=rechExpJuriJudi\&idTexte=JURITEXT0000345 
56153\&fastReqId $=1009431457 \&$ fastPos $=2$ visited on 29/7/2018.

French Court of Cassation, Commercial Room, Public Sitting of Wednesday 26 April 2017, No of Appeal: 15-27865.

Retrieved from https://www.legifrance.gouv.fr/affichJuriJudi.do?oldAction=rechExpJuriJudi\&idTexte=JURITEXT0000345 $56153 \&$ fastReqId $=1009431457 \&$ fastPos $=2$ visited on 5/8/2018.

French Court of Cassation, Commercial Room, Public Sitting of Wednesday 18 January 2017, No of Appeal: $15-13392$ 15-14661. Retrieved from https://www.legifrance.gouv.fr/affichJuriJudi.do?oldAction=rechExpJuriJudi\&idTexte=JURITEXT0000339 $03545 \&$ fastReqId $=950513147 \&$ fastPos $=94$ visited on $5 / 8 / 2018$.

Ghestin, J. (2007). La responsabilité délictuelle pour rupture abusive des pourparlers. JCP G, 155.

Giliker, P. (2003). Role for Tort in Pre-contractual Negotiations: an Examination of English, French, and Canadian Law. International and Comparative Law Quarterly, 52(Part 4), 969-994.

Grossman, N. (2017). Jettisoning the Normative Value of the Implied Duty of Good Faith in Employment Law. Employee Rights and Employment Policy Journal, 21(2), 377-408.

Hopkins, N. (2011). The Relevance of Context in Property Law: Case for Judicial Restraint. Legal Studies, 31(2), 175-198.

Jamal, M. (2002). The Willingness of Contracting. Beirut, Lebanon: Al-Halabi Legal Publications.

Juenger, F. K. (1994-1995). Listening to Law Professors Talk about Good Faith: Some Afterthoughts Tulane Law Review, 69(5), 1253-1280.

Korde, R. (2000). Good Faith and Freedom of Contract. UCL Jurisprudence Review 2000, 142-165.

Krauss, O. (2015-2016). The Enforceability of Escalation Clauses Providing for Negotiations in Good Faith under English Law. McGill Journal of Dispute Resolution, 2, 142-[ii].

Legrand, P. (2011). Foreign Law: Understanding Understanding. Journal of Comparative Law, 6(2), 67-177.

Li, X. (2017). The Legal Status of Pre-contractual Liability: Contrasting Responses from German and English Law. National Taiwan University Law Review, 12(1), 127-175.

Lou, S. (2017). Sino-philippine Arbitration on South China Sea Disputes: Perspective from the Principle of Good Faith. China Oceans Law Review 2017(1), 191-228.

Luksic, B., \& Jurilj, M. (2004). Principle of Good Faith in Contract Law. Zbornik Radova Pravnog Fakulteta Splitu, 41(1-2), 97-104.

Lutfi, H. M. (1995). Civil Responsibility in the Negotiation Phase, A Study in Egyptian and French Law. Cairo, Egypt: Al-Nasr Al-Dahabieh.

Marsh, P. D. V. (1994). Comparative Contract Law: England France, Germany. Hampshire, England: Aldershot.

Mato Pacin, M. (2015). Content Control of Sandard Terms in Business-to-business Contracts in Comparative and European Law. Cuadernos de Derecho Transnacional, 7(2), 216-282.

Mee, J. (2009). The Limits of Proprietary Estoppel: Thorner major. Child and Family Law Quarterly, 21(3), $367-383$.

Melhem, H. S. (2010). Negotiating Contracts Through the Internet. Nahrain University Journal, 13(2), 73-115.

Miller, A. D.; Perry, R. (2013). Good Faith Performance. Iowa Law Review 98(2), 689-746.

Musy, A. M. (2001). The Good Faith Principle in Contract Caw and the Pre-contractual Duty to Disclose: Comparative Analysis of New Differences in Legal Cultures. Global Jurist, 1(1), [i]-21.

Novoa, R. (2005). Culpa in Contrahendo: Comparative Law Study: Chilean Law and the United Nations Convention on Contracts for the International Sale of Goods (cisg). Arizona Journal of International and Comparative Law, 22(3), 583-612.

Nowicki, E. A. (2007). Director's Good Faith. Buffalo Law Review, 55(2), 457-536.

Perry, C. (2016). Good Faith in English and US Contract Law: Divergent Theories, Practical Similarities. Business Law International, 17(1), 27-40.

Piers, M. (2011). Good Faith in English Law Could Rule Become Principle. Tulane European and Civil Law Forum, 26, 123-170. 
Piska, N. (2009). Hopes, Expectations and Revocable Promises in Proprietary Estoppel. Modern Law Review, 72(6), 998-1015.

Principles of European Contract Law.

Procida Mirabeli di Lauro, A. (2016). L'Obbligazione Come Rapporto Complesso. Revista Brasileira de Direito Civil, 7, 132-189.

Rosher, P. (2015). New Developments in the Impending Reform of French Contract Law. International Business Law Journal, (6), 481-506.

Rosher, P. (2016). French contract law reform. Business Law International, 17(1), 59-72.

Russi, L. (2009). Substance or Mere Technique: a Precis on Good Faith Performance in England, France and Germany. Hanse Law Review, 5(1), 21-32.

Salama, A. A. (2001). International Contract Law, International Contract Negotiations, Law of will and its Crisis. Cairo, Egypt: Dar Alnahdah Alearabiah.

Salazar Revuelta, M., \& Herrera Bravo, R. (2017). Principia Iuris as Means of Harmonization and Unification of European Law through Historical-Comparative Methodology. GLOSSAE: European Journal of Legal History, 14, 819-865.

Saleh, A. A. (2011). Negotiations in International Commercial Contracts. Algeria, Algeria: Dar Houma.

Schmidt-Szalewski, J. (2000). La force obligatoire à l 'épreuve des avant-contrats. Paris, France: Dalloz.

Sejean, M. (2016). The French Reform of Contracts: An Opportunity to Tie Together the Community of Civil Lawyers. Louisiana Law Review, 76(4), 1151-1162.

Sic, M. (2012). Fides and Bona Fides in the Process of Creating ius Gentium. Zbornik Radova, 46(2), 157-176.

Spann, G. A. (2015). Good Faith Discrimination. William Mary Bill of Rights Journal, 23(3), 585-636.

Szalma, J. (2010). Liability for Conducting Negotiations in Bath Faith. Zbornik Radova, 44(3), 53-78.

Terré, F., Simler, P., \& Lequette, Y. (2002). Droit civil, Les obligations. Paris, France: Dalloz.

The EC Directive 93/13/EEC on Unfair Terms in Consumer Contracts.

The French Civil Code of 1804.

The New French Civil Code, which was created by Decree N 131-2016 of 10 February 2016.

The Official Explanatory of the Palestinian Civil Code Draft. Unpublished Manuscript.

The Palestinian Civil Code Draft (PDCC).

The Palestinian Law of Concerning Consumer Protection No. 21 of 2005.

The Palestinian Law of Insurance No. 20 of 2005.

Tourneau, P. L. (1998). La rupture des négociations. Revue Trimestrielle de.

UK Unfair Terms in Consumer Contracts Regulations of 1999 (1999 SI 2083).

UNIDROIT Principles of International Commercial Contracts.

van Erp, S. (1992). Good Faith: Concept Unworkable in Practice. Tilburg Foreign Law Review, 1(3), 215-226.

\section{Copyrights}

Copyright for this article is retained by the author(s), with first publication rights granted to the journal.

This is an open-access article distributed under the terms and conditions of the Creative Commons Attribution license (http://creativecommons.org/licenses/by/4.0/). 